\title{
Remediation of soil past erosion effects through amendments and agronomic practices
}

\author{
Wiqar Ahmad ${ }^{1 *}$ and Farmanullah Khan ${ }^{2}$ \\ ${ }^{1}$ Department of Soil and Environmental Sciences, University of Agriculture, Peshawar, Ameer Muhammad Khan Campus, Mardan, Pakistan. \\ ${ }^{2}$ Department of Soil and Environmental Sciences, University of Agriculture, Peshawar, Pakistan.
}

\begin{abstract}
In Pakistan there has been a trend to shift agriculture towards steep lands, where soil erosion is one of the most significant ecological restrictions to sustainable agricultural production. This study was focused to find ways to ameliorate the soil fertility degraded by past soil erosion. Different cropping patterns viz maize-wheat-maize rotation (C1), maize-lentil-maize rotation $(\mathrm{C} 2)$ and maize-wheat+lentil intercrop-maize rotation (C3) and different soil treatments, namely, the control (T1), $50 \%$ NP (also called the farmer's practice) (T2), $100 \%$ NPK or the recommended dose of NPK (T3) and $20 \mathrm{t} \mathrm{ha}^{-1}$ farmyard manure integrated with $50 \% \mathrm{~N}$ and $100 \% \mathrm{PK}$ (T4) were tested in a randomized complete block (RCB) design with split plot arrangements. Integrated use of organic manure (farmyard manure) and inorganic NPK fertilizers (T4) produced the highest wheat grain yield $\left(4730 \mathrm{~kg} \mathrm{ha}^{-1}\right)$, which was $9 \%$ higher than the $100 \%$ inorganic NPK (T3, $\left.4349 \mathrm{~kg} \mathrm{ha}^{-1}\right)$ and more than twice the control (T1, $\left.2072 \mathrm{~kg} \mathrm{ha}^{-1}\right)$. The increase in lentil grain yield in T4 (1112 $\left.\mathrm{kg} \mathrm{ha}^{-1}\right)$ was $7.4 \%$ higher than in the recommended NPK levels for lentils (T3, $\left.1035 \mathrm{~kg} \mathrm{ha}^{-1}\right)$ and $79 \%$ higher than the control. A significant nutrient enrichment and an improvement in soil fertility parameters was recorded by $\mathrm{T} 4$ over $\mathrm{T} 3$. This was further augmented by the application of cereal-legume rotation (C2) in the traditional cereal-cereal rotation (C1) and their combination showed a significantly improved residual effect on soil fertility in the subsequent year. In conclusion the degraded soil fertility of Missa gullied soil cannot be ameliorated to its full potential with only the recommended dose of mineral fertilizers. $50 \% \mathrm{~N}$ from organic fertilizer sources and the inclusion of legumes in the crop rotation is necessary to ensure agricultural sustainability on such soils.
\end{abstract}

Keywords: Agricultural sustainability, cropping patterns, eroded soil, farmyard manure, legumes, soil fertility.

\section{INTRODUCTION}

The increasing population and the attendant growing demand for food and fiber along with the shrinking of traditionally cultivable extent of land due to the development of infrastructure, has resulted in a trend to shift agriculture towards the sloping land areas in Northern Pakistan. Farmers lacking the knowledge regarding the land capability classification have been practicing the traditional cereal-cereal cropping system on these lands. Furthermore, the use of improper tilling and land levelling implements have exposed the soils resulting in erosion. The newly exposed soils being fragile, is easily affected by sheet and rill erosion, which removes the top fertile layer. During the field survey conducted under the supervision of Soil Survey Staff, Field Office Peshawar, Khyber Pakhtunkhwa, Pakistan in May 2006, calcium carbonate cankers were observed on the soil surface, which were assumed to have been exposed by the continuous removal of the plough layer due to erosion. Due to the continuous removal of the fertile surface, the soil layer has been exposed the fragile sub-surface soil and the cumulative effect resulted in the degradation of soil quality with respect to sustainable crop production. Furthermore, lack of knowledge regarding the proper dose and application methods of chemical fertilizers caused economic loss to the farmers and further deterioration of the soil environment (Yoo et al., 1974). The fertility and crop productivity of soils can be improved by practices that increase soil organic matter content (Banning et al., 2008). Previous investigations have shown that the potential of mineral 
fertilizers have increased in many folds when used in combination with organic sources (Yang et al., 2007; Purakayastha et al., 2008). To restore their natural fertility and crop productivity, these soils require careful handling and land management according to scientific recommendations.

The present study was, carried out on a severely eroded Missa gullied soil series in the Swabi District, Kyber Pakhtunkhwa Province, Pakistan during the period $2006-2008$, to study the effect of combined organic and inorganic fertilizer sources and the inclusion of legumes in the fixed cereal-cereal cropping system on the restoration of properties and nutrient status of soil. The application of organic and mineral fertilizers in integrated form was supposed to enhance the soil fertility and crop productivity on a sustained basis. The increase in soil organic matter content improved the soil structure, reducing soil fragility and susceptibility to erosion over time. The inclusion of legumes in crop rotations protects soil erosion by decreasing the flow velocity on the soil surface and may even counteract erosive forces by restoring the organic matter and $\mathrm{N}$ fertility of these soils. Soil fertility replenishment using a combination of organic and inorganic fertilizers increases the farm income and also minimizes the dependence on costly chemical fertilizers.

\section{METHODS AND MATERIALS}

\section{Site selection}

The selected study site was from a field in the village Maneri Payan, in the Swabi District. The study was conducted through a survey in collaboration with the Department of Soil Survey of Pakistan, Field Office Peshawar in May, 2006. Pre-sowing soil samples were collected from $0-20 \mathrm{~cm}$ and $20-40 \mathrm{~cm}$ depths and were analysed for the assessment of fertility status. The study site was classified according to the principles in Key to Soil Taxonomy (USDA, 1998). Pre-sowing soil fertility status and USDA classification of the experimental site are given in Table 1.

\section{Field experiment}

The field experiment was conducted during four consecutive seasons (Spring 2006, Fall 2006 - 2007, Spring 2007, Fall 2007 -2008) in a randomized complete block design with split plot arrangements. Treatment combinations for cropping patterns (main plot factor) and fertilizer treatment combinations for each crop (sub-plot factor) are given in Table 2. Each main plot and sub-plot factor were replicated three times. Maize

Table 1: Pre-sowing fertility status and USDA classification of the experimental site

\begin{tabular}{|c|c|c|c|}
\hline Property & & Mean value $(0-20 \mathrm{~cm})$ & Mean value $(20-40 \mathrm{~cm})$ \\
\hline Clay & & $32.1 \%$ & $37.0 \%$ \\
\hline Silt & & $53.2 \%$ & $49.1 \%$ \\
\hline Sand & & $14.7 \%$ & $13.9 \%$ \\
\hline Textural class & & Silty clay loam & Silty clay loam \\
\hline $\mathrm{pH}(1: 5)$ & & 7.96 & 8.2 \\
\hline $\mathrm{EC}(1: 5)$ & & $0.15 \mathrm{dS} \mathrm{m}^{-1}$ & $0.14 \mathrm{dS} \mathrm{m}^{-1}$ \\
\hline Organic matter & & $3.4 \mathrm{~g} \mathrm{~kg}^{-1}$ & $2.6 \mathrm{~g} \mathrm{~kg}^{-1}$ \\
\hline Lime $\left(\mathrm{CaCO}_{3}\right)$ & & $17.71 \%$ & $18.42 \%$ \\
\hline Total N & & $0.09 \mathrm{~g} \mathrm{~kg}^{-1}$ & $0.13 \mathrm{~g} \mathrm{~kg}^{-1}$ \\
\hline \multirow[t]{2}{*}{ Mineral N } & & $12.25 \mathrm{mg} \mathrm{kg}^{-1}$ & $5.54 \mathrm{mg} \mathrm{kg}^{-1}$ \\
\hline & & B-DTPA extractable & \\
\hline $\mathrm{P}$ & & $2.1 \mathrm{mg} \mathrm{kg}^{-1}$ & $2.25 \mathrm{mg} \mathrm{kg}^{-1}$ \\
\hline $\mathrm{K}$ & & $80.6 \mathrm{mg} \mathrm{kg}^{-1}$ & $68.9 \mathrm{mg} \mathrm{kg}^{-1}$ \\
\hline $\mathrm{Fe}$ & & $5.52 \mathrm{mg} \mathrm{kg}^{-1}$ & $3.52 \mathrm{mg} \mathrm{kg}^{-1}$ \\
\hline $\mathrm{Zn}$ & & $0.01 \mathrm{mg} \mathrm{kg}^{-1}$ & $0.06 \mathrm{mg} \mathrm{kg}^{-1}$ \\
\hline $\mathrm{Mn}$ & & $0.45 \mathrm{mg} \mathrm{kg}^{-1}$ & $0.57 \mathrm{mg} \mathrm{kg}^{-1}$ \\
\hline $\mathrm{Cu}$ & & $0.37 \mathrm{mg} \mathrm{kg}^{-1}$ & $0.26 \mathrm{mg} \mathrm{kg}^{-1}$ \\
\hline Local name & Soil series & Erosion hazard & USDA classification \\
\hline Stifa & Missa gullied & Severely eroded & $\begin{array}{l}\text { Coarse silty, mixed, } \\
\text { hyperthermic, } \\
\text { Udic Haplustalf }\end{array}$ \\
\hline
\end{tabular}


Table 2: Layout of the experiment

\begin{tabular}{|c|c|c|c|c|c|}
\hline \multirow{3}{*}{$\begin{array}{l}\text { Cropping } \\
\text { patterns }\end{array}$} & \multirow{3}{*}{ Crop seasons } & \multicolumn{3}{|c|}{ Treatments (R1) } & \multirow{3}{*}{$\begin{array}{c}\mathrm{T} 4 \\
20 \mathrm{t} \text { FYM }+ \\
50 \% \mathrm{~N}\end{array}$} \\
\hline & & $\mathrm{T} 1$ & $\mathrm{~T} 2$ & $\mathrm{~T} 3$ & \\
\hline & & Control & $50 \% \mathrm{NP}$ & $100 \%$ NPK & \\
\hline \multirow{4}{*}{$\mathrm{C} 1$} & Kharif 2006 & Maize & Maize & Maize & Maize \\
\hline & Rabi 2006 & Wheat & Wheat & Wheat & Wheat \\
\hline & Kharif 2007 & Maize & Maize & Maize & Maize \\
\hline & Rabi 2007 & Wheat & Wheat & Wheat & Wheat \\
\hline \multirow{4}{*}{$\mathrm{C} 2$} & Kharif 2006 & Maize & Maize & Maize & Maize \\
\hline & Rabi 2006 & Lentil & Lentil & Lentil & Lentil \\
\hline & Kharif 2007 & Maize & Maize & Maize & Maize \\
\hline & Rabi 2007 & Lentil & Lentil & Lentil & Lentil \\
\hline \multirow{4}{*}{$\mathrm{C} 3$} & Kharif 2006 & Maize & Maize & Maize & Maize \\
\hline & Rabi 2006 & $\mathrm{I} /$ Crop & I/Crop & I/Crop & I/Crop \\
\hline & Kharif 2007 & Maize & Maize & Maize & Maize \\
\hline & Rabi 2007 & I/Crop & I/Crop & I/Crop & I/Crop \\
\hline
\end{tabular}

Cont: (control treatment, $50 \% \mathrm{NP}$ : traditional fertilizer dose used by the farmers, $100 \%$ NPK: recommended fertilizer dose, FYM: farmyard manure

(Zea mays) variety 'Azam', Wheat (Triticum aestivum) variety 'Uqab' and lentil (Lens esculentum) variety 'MN-92' were grown during both seasons. The plot size was $20 \mathrm{~m}^{2}$. Urea, single super phosphate and potassium sulphate were used as inorganic fertilizer sources. Well decayed farmyard manure (FYM) was obtained from the Univeristy of Agricuture, Peshawar Dairy Farm and was applied during each season one month before field cultivation. In the case of $100 \% \mathrm{NPK}$, the fertilizer N was applied in two split treatments. At crop harvest, soil samples from $0-20$ and $20-40 \mathrm{~cm}$ depths were collected from each treatment plot for soil fertility analysis.

\section{Soil analysis}

Soil texture was determined by the procedure described by Tagar \& Bhatti (1996). The organic matter content in soil samples was determined by the Walkley-Black procedure (Nelson \& Sommers, 1982). Total soluble salts in the soil were determined by measuring soil electrical conductivity $(\mathrm{EC})$ in a 1:5 (soil: $\left.\mathrm{H}_{2} \mathrm{O}\right)$ suspension following $30 \mathrm{~min}$ of stirring and read on EC meter as reported by Rhodes (1996). Soil pH was measured in a 1:5 (soil: $\left.\mathrm{H}_{2} \mathrm{O}\right)$ suspension after $30 \mathrm{~min}$ of stirring and read on $\mathrm{pH}$ meter (Model German Type B-124 using glass and calomel

Table 3: Fertilizer treatments and cropping pattern combinations used in the experiment

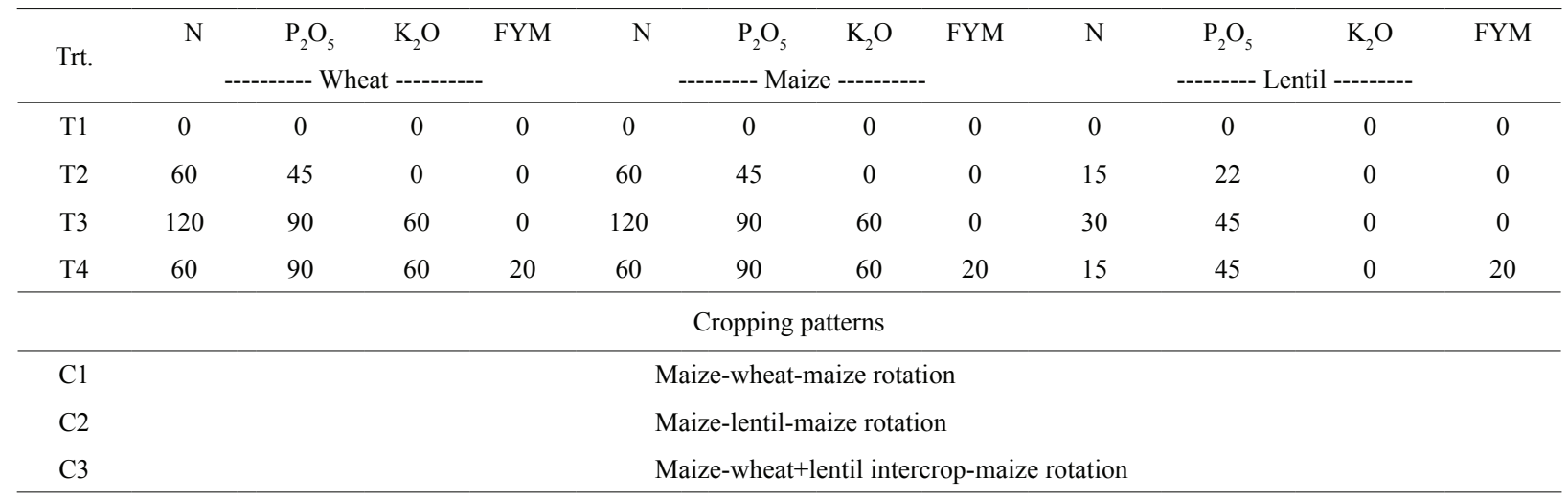

$\mathrm{N}, \mathrm{P}_{2} \mathrm{O}_{5}, \mathrm{~K}_{2} \mathrm{O}: \mathrm{kg} \mathrm{ha}^{-1}$, FYM: farmyard manure-t ha ${ }^{-1}$, Trt: treatments 
electrodes) (McLean, 1982). The lime content was determined by acid neutralization Method (US Salinity Lab Staff, 1954). AB-DTPA extractable P, K, Zn, Fe, and $\mathrm{Mn}$ were determined by the procedure described by Soltanpour and Schwab (1977). AB-DTPA extractable P was determined at $880 \mathrm{~nm}$ using a spectrophotometer. K was determined using a flame photometer and the micronutrients were determined using an atomic absorption spectrophotometer (Perkin Elmer Model 2380, USA) directly in filtrate. Mineral $\mathrm{N}$ was analyzed using the method developed by Mulvaney (1996). Total N in soil was determined by the Kjeldhal method of Bremner (1996) and total P, K and micronutrients in farmyard manure were determined by the perchloric acid-nitric acid digestion method as described by Kue (1996). For total $\mathrm{K}$, the solution was directly read on flame photometer and for micronutrients ( $\mathrm{Fe}, \mathrm{Zn}, \mathrm{Mn}, \mathrm{Cu})$, the solution was directly read on atomic absorption spectrophotometer (Perkin Elmer Model 2380, USA). The characteristics (A) and the quantity of nutrients $(\mathrm{kg})$ in the $20 \mathrm{t} \mathrm{ha}^{-1}$ of applied FYM (B) are given in Table 4.

\section{Statistical analysis}

The data collected from soil analysis was statistically analyzed using the analysis of variance (Gomez \& Gomez, 1984) using M.STATC and MS Excel softwares. Mean value for each parameter was calculated and the variation amongst means of different treatments/cropping patterns/ crop seasons were determined using LSD test of significance at the $\mathrm{p}<0.05$ level (Steel \& Torrie, 1980).

\section{RESULTS AND DISCUSSION}

\section{Effect of fertilizer treatments and cropping patterns on wheat productivity during 2007-2008}

The fertilizer treatments significantly $(\mathrm{p}<0.01)$ affected grain yield, biological yield and 1000 grain weight. The results (Table 5) revealed that integrated use of organic manure (farmyard manure) and inorganic NPK fertilizers (T4) produced the highest grain yield $\left(4730 \mathrm{~kg} \mathrm{ha}^{-1}\right)$, which was $9 \%$ higher than in the case of inorganic NPK $\left(\mathrm{T} 3,4349 \mathrm{~kg} \mathrm{ha}^{-1}\right)$ and more than twice that of the control $\left(\mathrm{T} 1,2072 \mathrm{~kg} \mathrm{ha}^{-1}\right)$. Similarly, the biological yield in T4 $\left(12.7 \mathrm{t} \mathrm{ha}^{-1}\right)$ was $12 \%$ higher than in T3 $\left(11.3 \mathrm{tha}^{-1}\right)$ and approximately 3 times higher than in the control plot (4.7 $\left.\mathrm{t} \mathrm{ha}^{-1}\right)$. The maximum 1000 grain weight was recorded in T4 (44 g) followed by T3 (43 g), while the lowest 1000 grain weight was recorded in the control (T1: 40 g). The improved organic and inorganic fertility due to the application of organic and inorganic fertilizers to the soil plus the residual effect of similar application to the previous crop, improved the availability of nutrients in T4 plots (Patra et al., 2000). Nutrients from the inorganic sources of fertilizers become readily available to the plants at their early growth stage whereas farmyard manure releases nutrients slowly for plant uptake, which

Table 4: (A) Characteristics of farmyard manure used in the experiment

\begin{tabular}{ll}
\hline Parameter & Value \\
\hline Moisture content & $47.5 \%$ \\
Total N & $10.6 \mathrm{~g} \mathrm{~kg}^{-1}$ \\
Total organic carbon (O.C) & $206.4 \mathrm{~g} \mathrm{~kg}^{-1}$ \\
$\mathrm{C} / \mathrm{N}$ ratio & 19.47 \\
Total P & $478.7 \mathrm{mg} \mathrm{kg}^{-1}$ \\
Total K & $2.9 \mathrm{~g} \mathrm{~kg}^{-1}$ \\
$\mathrm{Fe}$ & $0.11 \mathrm{~g} \mathrm{~kg}^{-1}$ \\
$\mathrm{Cu}$ & $22.57 \mathrm{mg} \mathrm{kg}^{-1}$ \\
$\mathrm{Zn}$ & $42.42 \mathrm{mg} \mathrm{kg}^{-1}$ \\
$\mathrm{Mn}$ & $121.75 \mathrm{mg} \mathrm{kg}^{-1}$ \\
\hline
\end{tabular}

(B) Quantity of nutrients (kg) in the $20 \mathrm{tha}^{-1}$ of applied FYM

\begin{tabular}{ccccccccc}
\hline \multirow{2}{*}{ Total N } & \multirow{2}{*}{ Total O.C } & \multicolumn{6}{c}{ AB-DTPA extractable } \\
& & $\mathrm{P}$ & $\mathrm{K}$ & $\mathrm{Fe}$ & $\mathrm{Zn}$ & $\mathrm{Mn}$ & $\mathrm{Cu}$ \\
\hline \multirow{2}{*}{212} & 4128 & 9.574 & 58 & 2.2 & 0.4514 & 0.8484 & 2.435 \\
\hline
\end{tabular}

Cost of FYM: Pak Rupees 1000 per 5 tons

Source: local market during 2005-2006 and 2006-2007 
become available at the latter stage of plant growth thus ensuring higher grain and biological yield and a higher 1000 grain weight. Mussgnug et al. (2006) has reported improved grain yield upon the application of farmyard manure to degraded soils.

There was some improvement in wheat yield due to the inclusion of legumes as an intercrop with wheat (C3) but that increase was statistically not significant compared to wheat only (C1) (Table 5). Continuous crops of cereals (C1) might have led to low or declining soil organic matter levels with associated chemical, physical and biological limitations on crop growth (Dalal \& Mayer, 1986). Furthermore, cereal-legume intercroping might have provided more space and sunlight to wheat rows in-between lentil rows causing vigorous vegetative growth of wheat crop along with other benefits of soil fertility (N-fixation). The results further showed that the cropping patterns and fertilizer treatments had significant $(p<0.05)$ interactive effect on 1000 grain weight of wheat whereas the interaction effect was not significant on the grain yield and biological yield. Thus improvement in 1000 grain weight was the result of both the effects of fertilizer treatments and cropping patterns

\section{Effect of fertilizer treatments and cropping patterns on lentil productivity during 2007 - 2008}

The fertilizers had a highly significant effect $(\mathrm{p}<0.01)$ on lentil grain yield, biological yield and 1000 grain weight (Table 6). The highest lentil grain yield was observed in T4 (1112 $\mathrm{kg} \mathrm{ha}^{-1}$ ), which was $7.4 \%$ higher than in the plot using the recommended NPK for lentils (T3, 1035 $\mathrm{kg} \mathrm{ha}^{-1}$ ) and $79 \%$ higher than the control (619 $\left.\mathrm{kg} \mathrm{ha}^{-1}\right)$. The maximum biological yield $\left(4.5 \mathrm{t} \mathrm{ha}^{-1}\right)$ was obtained in T4, which was $12.5 \%$ higher than in T3 and $87.5 \%$ higher than in the control $\left(2.4 \mathrm{t} \mathrm{ha}^{-1}\right)$. The results further indicated that the highest 1000 grain weight was recorded in T4 (22 g) followed by T3 (21 g) while the lowest 1000 grain weight (19 g) was observed in the control. The cropping pattern effect was also significant on the lentil grain yield $(p<0.05)$, the biological yield $(p<0.05)$ and the 1000 grain weight $(\mathrm{p}<0.01)$. The inbuilt mechanism of $\mathrm{N}_{2}$ fixation enables pulses to meet $80-90 \%$ of their $\mathrm{N}$ requirements but in the recent years, $20-30 \mathrm{~kg} \mathrm{ha}^{-1}$ of $\mathrm{S}$ and suitable doses of $\mathrm{Zn}, \mathrm{B}$, Mo and Fe have improved the productivity of pulses. Farmyard manure provides some of these nutrients depending upon the type of farmyard manure, hence T4 showed superiority in the yield and yield parameters of lentils. The carry-over effect of fertilizer applied to previous crops (Ali et al., 2008) and its resultant favourable soil environment synergistically improved the growth efficiency of the subsequent crop (Anderson, 2005). The inclusion of lentil in crop rotation (maize-lentil-maize, C2) produced higher lentil grain yield (1031 kg ha-1) as compared to lentil inclusion with wheat as an intercrop (C3, $\left.785 \mathrm{~kg} \mathrm{ha}^{-1}\right)$. Similarly, C2 also produced the highest biological yield $\left(4.0 \mathrm{t} \mathrm{ha}^{-1}\right)$ as compared to C3 (3.0 t ha-1) and the highest 1000 grain weight (26 g) as compared to C3 (14 g). Lentils in the intercrop with wheat suffered severe shading effect from wheat at the flowering stage, which caused reduction in the biological nitrogen fixation of lentils (Fujita et al.,

Table 5: Effect of fertilizer treatments and cropping patterns on wheat yield parameters during 2007-2008

\begin{tabular}{|c|c|c|c|}
\hline $\begin{array}{l}\text { Fertilizer } \\
\text { treatments }\end{array}$ & $\begin{array}{c}\text { Grain yield } \\
\left(\mathrm{kg} \mathrm{ha}^{-1}\right)\end{array}$ & $\begin{array}{c}\text { Biological yield } \\
\left(\mathrm{t} \mathrm{ha}^{-1}\right)\end{array}$ & $\begin{array}{l}1000 \text { grain weight } \\
(\mathrm{g})\end{array}$ \\
\hline $\mathrm{T} 1$ & $2072 \mathrm{~d}$ & $4.7 \mathrm{~d}$ & $40 \mathrm{~d}$ \\
\hline $\mathrm{T} 2$ & $3116 \mathrm{c}$ & $7.2 \mathrm{c}$ & $41 \mathrm{c}$ \\
\hline $\mathrm{T} 3$ & $4349 \mathrm{~b}$ & $11.3 \mathrm{~b}$ & $43 \mathrm{~b}$ \\
\hline $\mathrm{T} 4$ & $4730 \mathrm{a}$ & $12.7 \mathrm{a}$ & $44 \mathrm{a}$ \\
\hline $\operatorname{LSD}(<0.05)$ & 106.9 & 0.6 & 0.7 \\
\hline \multicolumn{4}{|c|}{ Cropping patterns } \\
\hline $\mathrm{C} 1$ & 3482 & 8.8 & 42 \\
\hline $\mathrm{C} 3$ & 3652 & 9.2 & 42 \\
\hline T-test & ns & ns & ns \\
\hline
\end{tabular}

Treatments: $\mathrm{T} 1=$ Control, $\mathrm{T} 2=\mathrm{N}: \mathrm{P}_{2} \mathrm{O}_{5}: \mathrm{K}_{2} \mathrm{O}\left(60: 45: 0 \mathrm{~kg} \mathrm{ha}{ }^{-1}\right), \mathrm{T} 3=\mathrm{N}: \mathrm{P}_{2} \mathrm{O}_{5}: \mathrm{K}_{2} \mathrm{O}$ $\left(120: 90: 60 \mathrm{~kg} \mathrm{ha}^{-1}\right) \mathrm{T} 4=\mathrm{N}: \mathrm{P}_{2} \mathrm{O}_{5}: \mathrm{K}_{2} \mathrm{O}\left(60: 90: 60 \mathrm{~kg} \mathrm{ha}^{-1}\right)+\mathrm{FYM}\left(20 \mathrm{t} \mathrm{ha}^{-1}\right)$

Cropping patterns $=$ Maize-Wheat-Maize (C1), Maize-wheat + lentil Intercrop-Maize (C3) Means followed by the same letters are not significantly different at the $\mathrm{p}<0.05$ level. 
Table 6: Effect of fertilizer treatments and cropping patterns on lentil yield parameters during $2007-2008$

\begin{tabular}{cccc}
\hline Fertilizer Treatments & $\begin{array}{c}\text { Grain yield } \\
\left(\mathrm{kg} \mathrm{ha}^{-1}\right)\end{array}$ & $\begin{array}{c}\text { Biological yield } \\
\left(\mathrm{t} \mathrm{ha}^{-1}\right)\end{array}$ & $\begin{array}{c}1000 \text { grain weight } \\
(\mathrm{g})\end{array}$ \\
\hline T1 & $619 \mathrm{~d}$ & $2.4 \mathrm{c}$ & $19 \mathrm{~d}$ \\
$\mathrm{~T} 2$ & $866 \mathrm{c}$ & $2.9 \mathrm{~b}$ & $20 \mathrm{c}$ \\
T3 & $1035 \mathrm{~b}$ & $4.0 \mathrm{a}$ & $21 \mathrm{~b}$ \\
T4 & $1112 \mathrm{a}$ & $4.5 \mathrm{a}$ & $22 \mathrm{a}$ \\
LSD (<0.05) & 42.6 & 0.5 & 0.6 \\
\hline Cropping patterns & & & $26 \mathrm{a}$ \\
\hline C2 & $1031 \mathrm{a}$ & $4.0 \mathrm{a}$ & $14 \mathrm{~b}$ \\
C3 & $785 \mathrm{~b}$ & $3.0 \mathrm{~b}$ & 0.002 \\
T-test & 0.001 & 0.02 & \\
\hline
\end{tabular}

Treatments: $\mathrm{T} 1=$ Control, $\mathrm{T} 2=\mathrm{N}: \mathrm{P}_{2} \mathrm{O}_{5}: \mathrm{K}_{2} \mathrm{O}\left(60: 45: 0 \mathrm{~kg} \mathrm{ha}^{-1}\right), \mathrm{T} 3=\mathrm{N}: \mathrm{P}_{2} \mathrm{O}_{5}: \mathrm{K}_{2} \mathrm{O}\left(120: 90: 60 \mathrm{~kg} \mathrm{ha}^{-1}\right)$, $\mathrm{T} 4=\mathrm{N}: \mathrm{P}_{2} \mathrm{O}_{5}: \mathrm{K}_{2} \mathrm{O}\left(60: 90: 60 \mathrm{~kg} \mathrm{ha}^{-1}\right)+\mathrm{FYM}\left(20 \mathrm{tha}^{-1}\right)$.

Maize-Lentil-Maize (C2), Maize-Intercrop-Maize (C3)

Means followed by the same letters are not significantly different at the $\mathrm{p}<0.05$ level.

1992) causing a reduced grain yield, biological yield and 1000 grain weight. The high root density of wheat for extracting of nutrients from the already nutrient deficient soil leaves an improper nutrient balance for lentils and this resulted in the reduction of intercropped lentil yield. The interaction effect between fertilizer treatments and cropping patterns on lentil 1000 grain weight was highly significant as the increase in 1000 grain weight in lentil was due to the combined effect of fertilizer treatments and cropping patterns. The interaction effect on the lentil grain yield and biological yield was not significant.

\section{Variation in soil fertility status due to fertilizer treatments and cropping patterns}

\section{Mineral N $\left(\mathrm{mg}_{\mathrm{g}^{-1}}\right)$}

The amount of available mineral nutrients in soil indicates the level of soil fertility resulting from long-term crop and soil management practices. Determination of the mineral nutrient levels in soil was therefore essential to confirm the sustainability of the soil and crop management practices. Different combinations of fertilizer applications significantly $(\mathrm{p}<0.01)$ increased the mineral $\mathrm{N}$ content both in the surface $(0-20 \mathrm{~cm})$ and sub-surface $(20-40$ $\mathrm{cm})$ soil as compared to soils that received no fertilizer (the control). It was observed (Table 7) that fertilizers in its integrated form (T4) showed the maximum increase in mineral $\mathrm{N}(69 \%)$ over the control in surface soil $(0-20 \mathrm{~cm})$. Mineral fertilizer alone, $100 \%$ NPK treatment (T3) and $50 \% \mathrm{NP}$ treatment (T2) also showed increases in the mineral $\mathrm{N}$ content but the performance of integrated organic and inorganic fertilization (T4) was superior over the mineral fertilizer treatments (T3 and $\mathrm{T} 2$ ). The increase in mineral $\mathrm{N}$ content in $\mathrm{T} 4$ was $13 \%$ over T3. A similar trend of increase in mineral $\mathrm{N}$ content with fertilizer application both in organic and inorganic form was observed in sub-surface soil (20-40 $\mathrm{cm})$. The higher mineral $\mathrm{N}$ in $\mathrm{T} 4$ might be due to the mineralization of FYM in addition to the $50 \%$ mineral $\mathrm{N}$ applied. The post-harvest inorganic $\mathrm{N}$ increase in soil could be related to the amount of manure and fertilizer $\mathrm{N}$ applied (Jokela, 1992). Farmyard manure has been a source of nutrients and also improves the efficiency of fertilizer use (Swarup, 2001) thereby reducing the loss of applied mineral $\mathrm{N}$ from soil (Patra et al., 2000).

The results showed that the cropping patterns significantly $(\mathrm{p}<0.01)$ affected mineral $\mathrm{N}$ in the surface $(0-20 \mathrm{~cm})$ soil, while in sub-surface $(20-40 \mathrm{~cm})$ its effect on mineral $\mathrm{N}$ was not significant (Table 8). It was observed that mineral $\mathrm{N}$ content in the cereal-legume rotation $(\mathrm{C} 2)$ was the highest $\left(25.3 \mathrm{mg} \mathrm{kg}^{-1}\right)$ and it was $10 \%$ and $16 \%$ higher over the cereal-cereal rotation $\left(\mathrm{C} 1,22.8 \mathrm{mg} \mathrm{kg}^{-1}\right)$ and cereal-legume intercrop (C3, $19.7 \mathrm{mg} \mathrm{kg}^{-1}$ ), respectively. Legumes not only provide additional $\mathrm{N}$ through $\mathrm{NO}_{3}^{-}$spraying (Evans et al., 1991) and the mineralization of fixed $\mathrm{N}$ in the residues but also capture soil available $\mathrm{N}$ and reduce $\mathrm{NO}_{3}$ losses from 


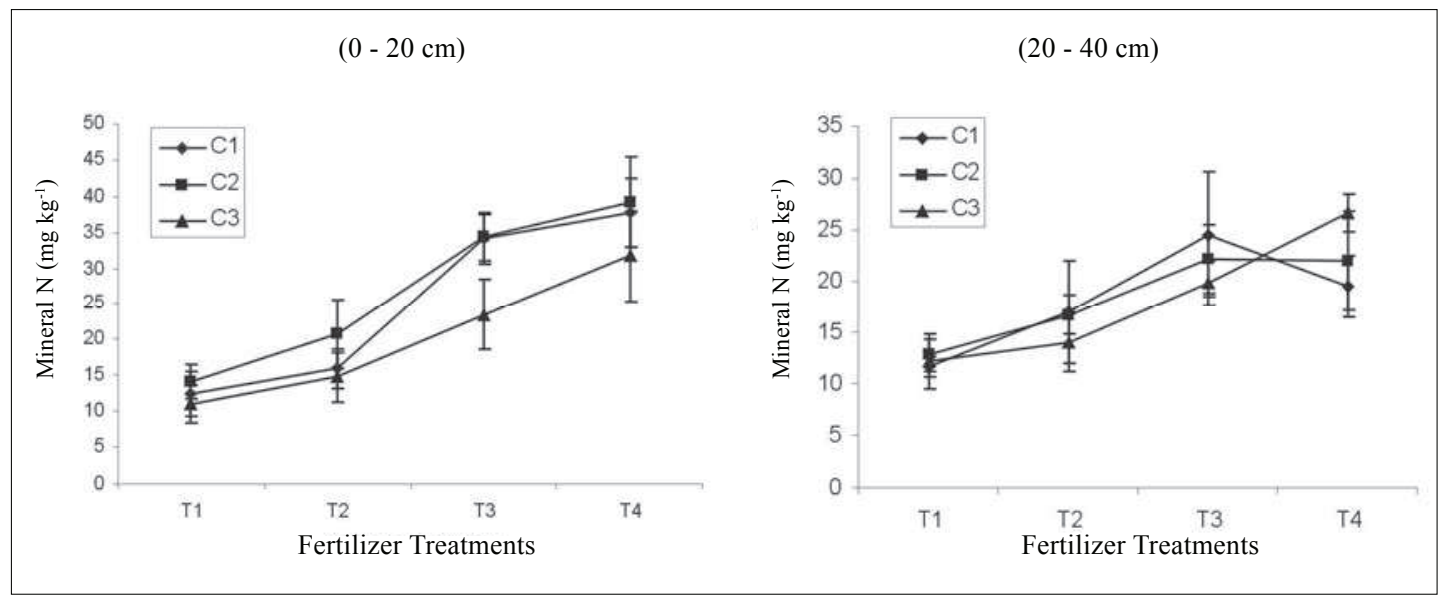

Figure 1: Interaction effect between fertilizer treatments and cropping patterns on mineral $\mathrm{N}$ content in surface and sub - surface soil

soil (Campbell et al., 1991). Furthermore, fertilizer (as starter dose) and FYM application to legumes may have increased the population of nitrogen fixing bacteria, which may have increased the $\mathrm{N}$ content in the soil (Basu et al., 2008). Biological $\mathrm{N}$ fixation by legumes and their nodulated roots left over in the soil after crop harvest has been considered a very important source of organic nitrogen input to the soil (Wartainen et al., 2008).

It is further observed that the nutrient concentration decreased with increasing depth. Taking the average of all the fertilizer treatments (T1 to T4), it was noted that mineral $\mathrm{N}$ content in surface soil was $20.5 \%$ higher over the sub-surface soil. In surface soil, the higher nutrient balance might be due to the surface application of inorganic $\mathrm{N}$ or due to its accumulation in the soil from mineralization of organic matter added through farmyard manure, a portion of which leaches down through the soil profile (Crews \& Peoples, 2004).

The data analysis shows that the interaction effect between fertilizer treatments and cropping patterns on mineral $\mathrm{N}$ content was not significant in surface soil, while in sub-surface soil $(20-40 \mathrm{~cm})$, the interaction effect on mineral $\mathrm{N}$ content was significant $(\mathrm{p}<0.05)$. Thus, the fertilizer treatments and cropping patterns increased the

Table 7: Effect of fertilizer treatments on soil fertility status

\begin{tabular}{|c|c|c|c|c|c|c|c|c|c|c|}
\hline Parameters & $\mathrm{T} 1$ & $\mathrm{~T} 2$ & $\mathrm{~T} 3$ & $\mathrm{~T} 4$ & $\begin{array}{c}\text { LSD } \\
(<0.05)\end{array}$ & $\mathrm{T} 1$ & $\mathrm{~T} 2$ & $\mathrm{~T} 3$ & $\mathrm{~T} 4$ & $\begin{array}{l}\text { LSD } \\
(<0.05)\end{array}$ \\
\hline & \multicolumn{5}{|c|}{------------------ 0 - 20 cm ----------------- } & \multicolumn{5}{|c|}{--------------------- 20 - 40 cm ------------- } \\
\hline Min. $N\left(\mathrm{mg} \mathrm{kg}^{-1}\right)$ & 10.6 & 15.0 & 30.4 & 34.3 & 1.9 & 11.9 & 15.6 & 22.1 & 22.2 & 2.4 \\
\hline $\mathrm{O} . \mathrm{M}\left(\mathrm{g} \mathrm{kg}^{-1}\right)$ & 4.3 & 5.2 & 5.9 & 8.2 & 0.6 & 3.7 & 4.7 & 5.3 & 6.0 & 0.4 \\
\hline Soil pH & 7.91 & 7.87 & 7.82 & 7.75 & 0.3 & 7.91 & 7.9 & 7.87 & 7.87 & ns \\
\hline E.C. $\left(\mathrm{dS} \mathrm{m}^{-1}\right)$ & 0.18 & 0.21 & 0.28 & 0.30 & 0.01 & 0.17 & 0.21 & 0.29 & 0.33 & 0.01 \\
\hline \multicolumn{11}{|c|}{ AB-DTPA extractable $\left(\mathrm{mg} \mathrm{kg}^{-1}\right)$} \\
\hline $\mathrm{P}$ & 3.0 & 5.2 & 6.8 & 9.7 & 0.8 & 2.5 & 3.2 & 3.8 & 4.8 & 0.3 \\
\hline K & 61.8 & 63.4 & 93.4 & 107.8 & 3.8 & 55.7 & 58.9 & 75.8 & 82.0 & 3.5 \\
\hline $\mathrm{Fe}$ & 4.1 & 4.3 & 5.0 & 6.9 & 0.4 & 4.1 & 4.0 & 3.8 & 5.4 & 0.3 \\
\hline $\mathrm{Zn}$ & 0.5 & 0.8 & 1.2 & 1.8 & 0.3 & 0.6 & 0.6 & 0.8 & 1.3 & 0.17 \\
\hline $\mathrm{Mn}$ & 2.2 & 2.9 & 3.0 & 5.0 & 0.6 & 2.5 & 2.2 & 2.5 & 3.5 & 0.6 \\
\hline $\mathrm{Cu}$ & 0.6 & 0.7 & 0.8 & 1.8 & 0.1 & 0.6 & 0.6 & 0.8 & 1.6 & 0.1 \\
\hline
\end{tabular}

Note: Data has been combined from 4 seasons, 3 cropping patterns and 3 repeats at each treatment application.

Treatments: $\mathrm{T} 1=$ Control, $\mathrm{T} 2=\mathrm{N}: \mathrm{P}_{2} \mathrm{O}_{5}: \mathrm{K}_{2} \mathrm{O}\left(60: 45: 0\right.$ and 15:22 $\left.\mathrm{kg} \mathrm{ha}^{-1}\right), \mathrm{T} 3=\mathrm{N}: \mathrm{P}_{2} \mathrm{O}_{5}: \mathrm{K}_{2} \mathrm{O}(120: 90: 60$ and 30:45 kg ha-1 $), \mathrm{T} 4=\mathrm{N}$ : $\mathrm{P}_{2} \mathrm{O}_{5}: \mathrm{K}_{2} \mathrm{O}\left(60: 90: 60\right.$ and 15:45 kg ha-1) + FYM $\left(20 \mathrm{t} \mathrm{ha}^{-1}\right)$, O.M.- Organic matter, Min. N - Mineral nitrogen 
Table 8: Effect of cropping patterns on soil fertility status

\begin{tabular}{|c|c|c|c|c|c|c|c|c|}
\hline Parameters & $\mathrm{C} 1$ & $\mathrm{C} 2$ & $\mathrm{C} 3$ & $\begin{array}{l}\text { LSD } \\
(<0.05)\end{array}$ & $\mathrm{C} 1$ & $\mathrm{C} 2$ & $\mathrm{C} 3$ & $\begin{array}{c}\text { LSD } \\
(<0.05)\end{array}$ \\
\hline & \multicolumn{4}{|c|}{------------------------ 0 - 20 cm ----------------- } & \multicolumn{4}{|c|}{---------------------- 20 - 40 cm --------------- } \\
\hline Min. $N\left(\mathrm{mg} \mathrm{kg}^{-1}\right)$ & 22.8 & 25.3 & 19.7 & 2.0 & 17.7 & 18.0 & 18.2 & ns \\
\hline O.M. $\left(\mathrm{g} \mathrm{kg}^{-1}\right)$ & 5.0 & 6.9 & 5.6 & 0.5 & 4.5 & 5.4 & 4.9 & 0.6 \\
\hline Soil $\mathrm{pH}$ & 7.84 & 7.82 & 7.85 & ns & 7.87 & 7.88 & 7.91 & ns \\
\hline E.C. $\left(\mathrm{dS} \mathrm{m}^{-1}\right)$ & 0.24 & 0.24 & 0.24 & ns & 0.25 & 0.25 & 0.24 & ns \\
\hline \multicolumn{9}{|c|}{ AB-DTPA extractable $\left(\mathrm{mg} \mathrm{kg}^{-1}\right)$} \\
\hline $\mathrm{P}$ & 6.0 & 6.2 & 6.4 & ns & 3.4 & 3.6 & 3.7 & $\mathrm{~ns}$ \\
\hline K & 85.4 & 77.5 & 83.7 & 3.4 & 69.0 & 66.5 & 68.8 & ns \\
\hline $\mathrm{Fe}$ & 4.77 & 5.2 & 5.25 & $\mathrm{~ns}$ & 4.11 & 4.34 & 4.46 & $\mathrm{~ns}$ \\
\hline $\mathrm{Zn}$ & 0.91 & 1.04 & 1.2 & ns & 0.77 & 0.87 & 0.86 & ns \\
\hline $\mathrm{Mn}$ & 3.14 & 3.24 & 3.41 & ns & 2.67 & 2.98 & 2.48 & $\mathrm{~ns}$ \\
\hline $\mathrm{Cu}$ & 0.98 & 1.05 & 0.88 & ns & 0.87 & 1.04 & 0.85 & ns \\
\hline
\end{tabular}

Note: Data have been combined from 4 seasons, 4 fertilizer treatments and 3 repeats at each treatment application.

Maize-Wheat-Maize (C1), Maize-Lentil-Maize (C2), Maize-Intercrop-Maize (C3), O.M. - Organic matter, Min. N - Mineral nitrogen

mineral $\mathrm{N}$ content in surface soil independent of each other, while the gradual increase in mineral $\mathrm{N}$ content in sub-surface soil was due to the combined effect of fertilizer application and cropping patterns. It may also be due to the fact that the plants/crop were feeding from the surface soil depleting the $\mathrm{N}$ reserve while in the sub-surface soil, the roots of the previous crop and the current crop served as reserves of $\mathrm{N}$ supply upon its decomposition. It may be due to $\mathrm{N}$ leaching and its illuvation in sub-surface soil.

\section{AB-DTPA extractable P $\left(\mathrm{mg}_{\mathrm{kg}}^{-1}\right)$}

The fertilizer treatments significantly $(\mathrm{p}<0.01)$ affected AB-DTPA extractable $P$ content both in surface $(0-20 \mathrm{~cm})$ and sub-surface $(20-40 \mathrm{~cm})$ soil as compared to soils that received no fertilizer (the control). It was observed (Table 7) that fertilizers in the integrated form (T4) resulted in high increase in AB-DTPA extractable P (69\%) over the control treatment in surface soil $(0-20 \mathrm{~cm})$ and $79 \%$ in the sub-surface $(20-40 \mathrm{~cm})$ soil while its improvement in the AB-DTPA extractable P over the recommended dose of NPK (T3) and farmers practice (T2) was 30 and $46 \%$ in surface and 16 and $34 \%$ in sub-surface soils, respectively. The surface application of $\mathrm{P}$ both in mineral form and the P released by FYM through mineralization caused higher $\mathrm{P}$ content in T4. These results are in agreement with those of Morari et al. (2008) in which a higher available $\mathrm{P}$ with the use

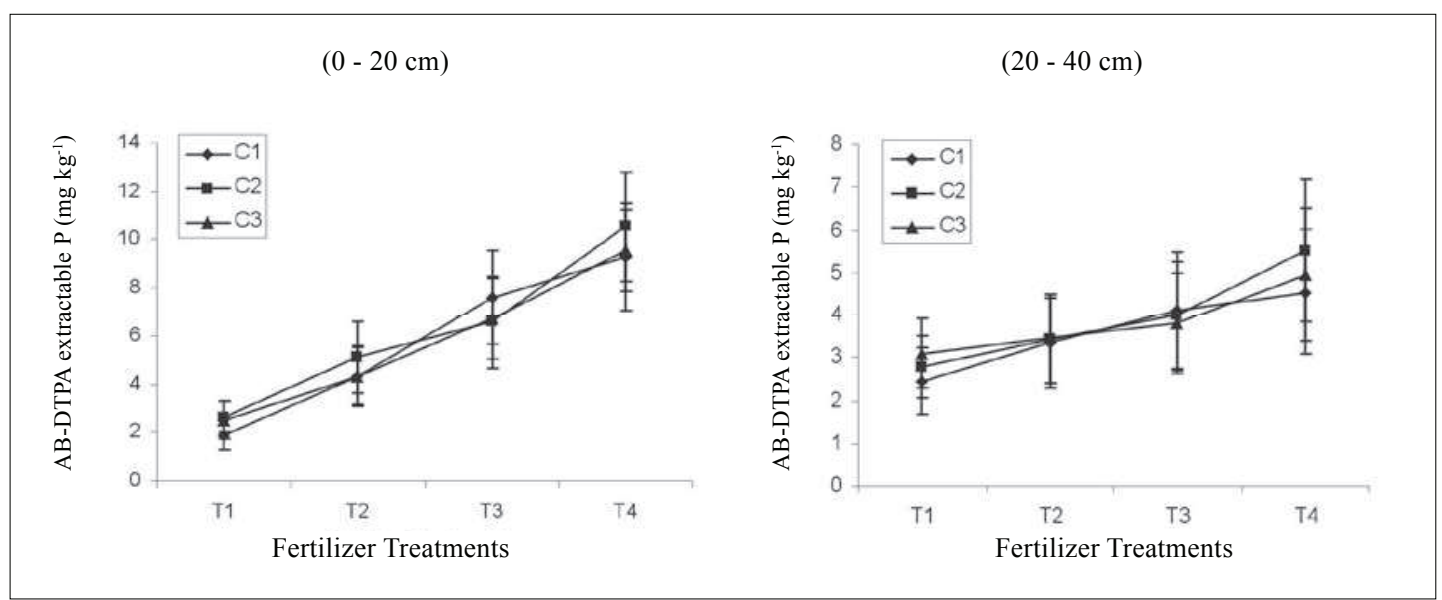

Figure 2: Interaction effect between fertilizer treatments and cropping patterns on AB-DTPA extractable P content in surface and sub-surface soil 
of organic fertilizers was reported. The increased microbial activity with the combined application of farmyard manure (Ayaga et al., 2006) and P fertilizers increased the cycling of $\mathrm{P}$ through microbiological processes, thus decreasing $\mathrm{P}$ fixation and increased plant availability with time. The higher available $\mathrm{P}$ in $\mathrm{T} 3$ could be attributed to the mineral $\mathrm{P}$ applied in excess to that removed by the crop. These findings are in line with the findings of McCullum (1991) who reported that the application of $\mathrm{P}$ in excess to that removed by harvested crops can result in a large build-up of soil P reserves.

The results (Table 8) further showed that the cropping patterns containing legumes either as sole crop (C2) or inter cropped with cereal (C3) registered a non-significant increase in AB-DTPA extractable $\mathrm{P}$ over cereal-cereal rotation $(\mathrm{C} 1)$ at both depths. The higher AB-DTPA extractable $\mathrm{P}$ in cereal-legume rotation may be attributed to the $\mathrm{P}$ fertilizer application to legume crops and altering the $\mathrm{pH}$ of the rhizosphere (Wilson et al., 1982). This might also be attributed to cycling of $\mathrm{P}$ through the soil microbiological and associated metabolite pools, thus decreasing $\mathrm{P}$ fixation and increased plant availability (Ayaga et al., 2006).

The data analysis showed that the interaction effect between fertilizer treatments and cropping patterns on soil AB-DTPA extractable $\mathrm{P}$ was insignificant in surface soil $(0-20 \mathrm{~cm})$. In sub-surface soil $(20-40$ $\mathrm{cm})$, the interaction effect was significant on AB-DTPA extractable $\mathrm{P}(\mathrm{p}<0.05)$. Similar to mineral $\mathrm{N}$, the increase in $\mathrm{P}$ in the surface soil due to fertilizer treatments and cropping patterns was independent of each other whereas it was due to the combined effect of fertilizer treatments and cropping patterns in the sub-surface soil. Similar to mineral N, P depleted from surface soil while it accumulated in the sub-surface soil due to either leaching of dissolved organic matter (OM) or due to the increased microbial activity, which might have increased its mineralization and unlocking of the fixed P.

\section{AB-DTPA extractable $\mathrm{K}\left(\mathrm{mg} \mathrm{kg}^{-1}\right)$}

The fertiizer application significantly $(\mathrm{p}<0.01)$ increased AB-DTPA extractable $\mathrm{K}$ content in both the surface $(0-20 \mathrm{~cm})$ and sub-surface $(20-40 \mathrm{~cm})$ soil. Based on the data averaged over seasons (Table 7), it was observed that T4 recorded the maximum $(107.8 \mathrm{mg}$ $\mathrm{kg}^{-1}$ ) AB-DTPA extractable $\mathrm{K}$ in surface soil followed by T3 (93.4 $\left.\mathrm{mg} \mathrm{kg}^{-1}\right)$ and T2 $\left(63.4 \mathrm{mg} \mathrm{kg}^{-1}\right)$ while the lowest AB-DTPA extractable $\mathrm{K}\left(61.8 \mathrm{mg} \mathrm{kg}^{-1}\right)$ was observed in the control (T1). A similar trend was also observed in sub-surface soil. Thus, the integrated application of fertilizer (T4) registered $13 \%$ higher AB-DTPA extractable $\mathrm{K}$ than in the treatment with recommended NPK (T3), $41 \%$ higher than the farmers practice (T2) and $43 \%$ higher than the control in surface soil. In subsurface soil, this increase over T3, T2 and the control was $7.6,28$ and $32 \%$, respectively. The additional $\mathrm{K}$ coming from farmyard mineralization further increased the $\mathrm{K}$ content in addition to the $100 \%$ mineral $\mathrm{K}$ applied in T4. The results confirms the findings of Blaise et al. (2005) who had found that the K balance was positive only when FYM was applied. Dressel et al. (1993) have reported that medium and high fertilization of soil caused enrichment of $\mathrm{K}$ in top soil. AB-DTPA extractable $\mathrm{K}$ in the surface soil is $16.5 \%$ higher over the sub-surface soil. This might be due to the decreasing organic matter content with the depth, having a highly significant correlation (0.86) with $\mathrm{K}$ content and these results are in line with the results of Bullock (1992) who also reported a $\mathrm{K}$ increase with the increasing organic matter content.

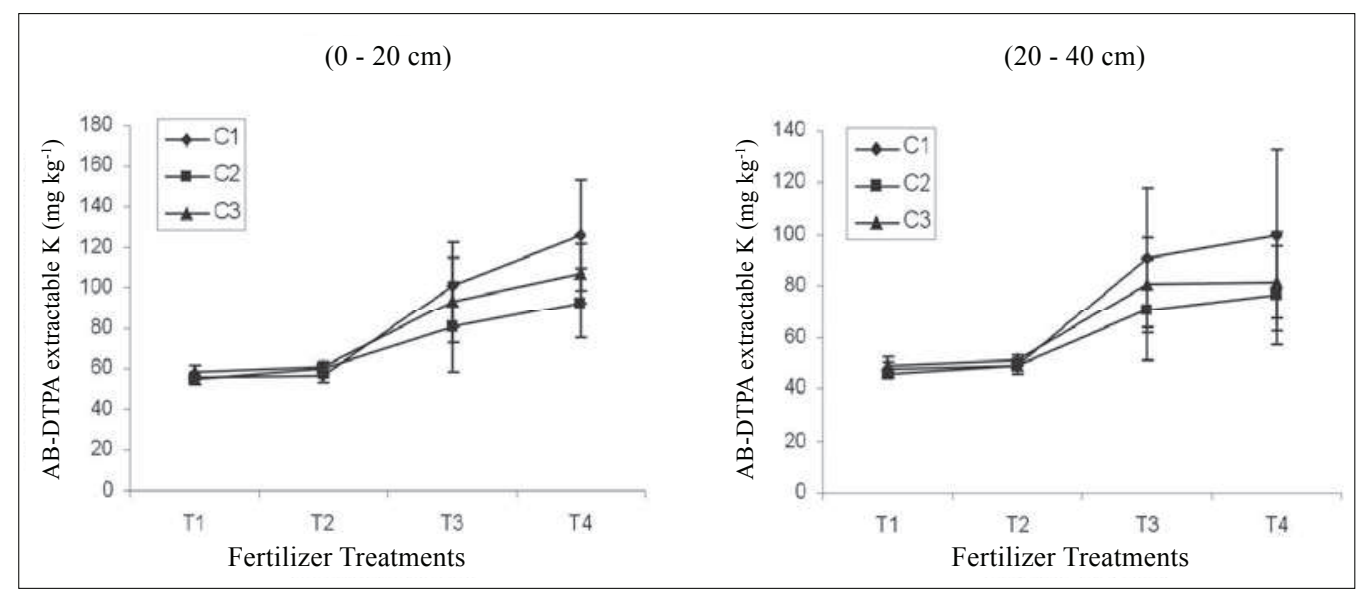

Figure 3: Interaction effect between fertilizer treatments and cropping patterns on AB-DTPA extractable K content in surface and sub-surface soil 
The effect of cropping pattern on AB-DTPA extractable $\mathrm{K}$ was also highly significant $(\mathrm{p}<0.01)$ in the surface soil $(0-20 \mathrm{~cm})$ and not significant in the sub-surface $(20-40 \mathrm{~cm})$ soil. The cereal-cereal rotation $(\mathrm{C} 1)$ recorded $9.2 \%$ higher AB-DTPA extractable $\mathrm{K}$ content than in cereal-legume rotation $(\mathrm{C} 2)$ whilst in the cereal-cereal rotation (C1) and cereal-legume intercrop (C3), the means were statistically similar (Table 4). A significantly higher $\mathrm{K}$ content in the cereal-cereal rotation $(\mathrm{C} 1)$ followed by cereal-legume intercrop (C3) might be attributed to the surface application of $100 \% \mathrm{~K}$ in T3 and T4. Bengtson et al. (2003) also found a positive $\mathrm{K}$ balance in the conventional system instead of the organic system.

The data analysis showed that the interaction effect between fertilizer treatments and cropping patterns on AB-DTPA extractable $\mathrm{K}$ was highly significant $(\mathrm{p}<0.01)$ in the surface soil, while in the sub-surface soil $(20-40 \mathrm{~cm})$ the interaction effect between fertilizer treatments and cropping patterns was not significant. Thus, the significant variation in the $\mathrm{K}$ content in surface soil is due to the combined effect of fertilizer application at various doses and forms and at various rates recommended for different cropping patterns. The maximum increase in $\mathrm{T} 4 \times \mathrm{C} 1$ plot might be due to the $100 \%$ inorganic $\mathrm{K}\left(60 \mathrm{~kg} \mathrm{ha}^{-1}\right)$ application and the $\mathrm{K}$ mineralization from FYM applied. In T4 × C3 plot, the $100 \%$ inorganic $\mathrm{K}$ was applied to only wheat rows (a total of $30 \mathrm{~kg} \mathrm{ha}^{-1}$ ) combined with the $\mathrm{K}$ from the FYM mineralization, thus it was the second in $\mathrm{K}$ content amongst $\mathrm{T} 4$ treatments, while $\mathrm{T} 4 \times \mathrm{C} 2$ showed the lowest $\mathrm{K}$ content amongst $\mathrm{T} 4$ treatments due to no inorganic application into $\mathrm{C} 2$ cropping patterns.

\section{Soil organic matter $\left(\mathrm{g}^{-1}\right)$}

The fertilizer application significantly $(\mathrm{p}<0.01)$ increased the OM content both in the surface $(0-20 \mathrm{~cm})$ and subsurface $(20-40 \mathrm{~cm})$ soil as compared to the control. It was observed (Table 7) that fertilizers in integrated form (T4) showed the maximum soil OM content (8.2 and $6 \mathrm{~g} \mathrm{~kg}^{-1}$ ), which was $47.6 \%$ and $38 \%$ higher than in the control in surface and sub-surface soil, respectively. It was further noted that the same treatment (T4) also recorded $28 \%$ and $11.7 \%$ higher soil OM content over the recommended dose of NPK (T3) in surface and sub-surface soil, respectively. With regard to the farmers practice (T2), this increase was 36.6 and $21.7 \%$, respectively. Farmyard manure and fertilizer applications are important management practices used to improve the nutrient status and organic matter in soils and thus to increase the crop productivity (Yang et al., 2007). Monaco et al. (2008) also found a higher OM content in FYM treated soil. When animal manure with a plant nutrient content equivalent to that of the mineral fertilizers is applied, the soil receives an additional input of organic material, which is equivalent to the difference in the organic matter derived from the mineral fertilizers alone and that with farmyard manure (Christensen, 1988). Organic matter in inorganic fertilizer plots was significantly higher than the control plots. The effect of mineral fertilizers on soil organic matter content might, at least partly, be compared to that of straw incorporation (Christensen, 1988).

The effect of cropping pattern on soil OM content was also highly significant $(p<0.01)$ both in surface $(0-20 \mathrm{~cm})$ and sub-surface $(20-40 \mathrm{~cm})$ soil. The

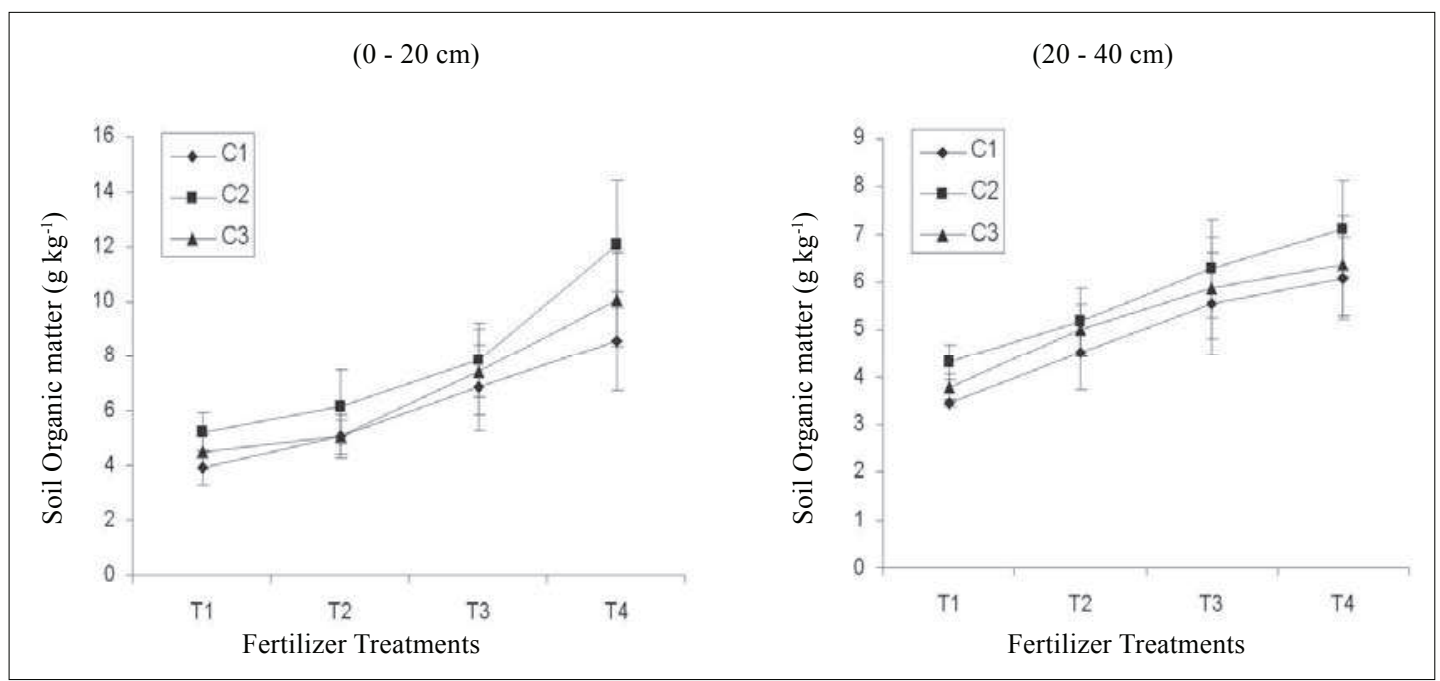

Figure 4: Interaction effect between fertilizer treatments and cropping patterns on soil organic matter content in surface and sub-surface soil 
results (Table 8) showed that the highest organic matter content (6.9 $\mathrm{g} \mathrm{kg}^{-1}$ ) was recorded in cereal-legume rotation $(\mathrm{C} 2)$, which was $27 \%$ higher than the cerealcereal rotation $(\mathrm{C} 1)$ and $23 \%$ higher than the cereallegume intercrop (C3). In sub-surface soil, the cereallegume rotation (C2) showed a $20 \%$ and $10 \%$ increase in soil OM content over the cereal-cereal rotation $(\mathrm{C} 1)$ and cereal-legume intercrop (C3), respectively. Similar to $\mathrm{N}, \mathrm{P}$ and $\mathrm{K}$, a decreasing trend in soil OM content was observed with depth in respective fertilizer treatments. At maturity, the lentils shed more than half of its leaves producing a thin layer of litter on the soil surface, which is equivalent to the application of organic material to soil that increased organic matter and soil nutrient content (Courtney \& Mullen, 2008). In C1 (cerealcereal rotation), the low organic matter content might be due to the intensive crop production and the higher organic matter mineralization that prevent organic matter accumulation in soil. These findings are in line with Zhao et al. (2008) who found a lowest organic C and higher mineralization in an intensive crop production system. In C2 (cereal-legume rotation) the process was opposit to that in C1. Purakayastha et al. (2008) have reported that the increase in soil organic carbon concentration under long term cereal-legume cropping systems was due to the fact that the annual $\mathrm{C}$ input by the system was higher than the annual exhaust. Ussiri et al. (2006) reported that below - ground biological parts are also an important source of $\mathrm{C}$ in soils, especially in the sub-surface.

The data analysis showed that the interaction effect between fertilizer treatments and cropping patterns on soil OM was highly significant $(\mathrm{p}<0.01)$ in the surface soil and not significant in the sub-surface soil $(20-40 \mathrm{~cm})$.
Thus, the variation in soil OM in surface soil was due to the combined effect of fertilizers and cropping patterns, while in sub-surface soil, the effect of fertilizer treatments and cropping patterns on soil OM was independent of each other. This might be due to the surface application of FYM and the higher content of residues received by the surface soil as compared to the sub-surface soil.

\section{Soil pH}

Based on the pooled data over seasons, a significant $(\mathrm{p}<0.05)$ reduction in soil $\mathrm{pH}$ was observed due to the application of fertilizers both in the organic and inorganic forms. It was noted from the data (Table 7), that mixed fertilizer application (organic and inorganic) recorded the maximum $2 \%$ reduction in soil $\mathrm{pH}$ over the control while reduction in soil $\mathrm{pH}$ in the same treatment over the recommended NPK (T3) and farmer's practice (T2) was 0.9 and $1.4 \%$, respectively. The data (Table 7) further showed that the fertilizer treatment effect on soil $\mathrm{pH}$ was non-significant in sub-surface soil. Simek et al. (1999) have reported that the effects of the manure and inorganic fertilizers reduced soil $\mathrm{pH}$. Numerous studies have reported soil acidification with continuous use of nitrogenous fertilizers (Fox \& Hoftinan, 1981; Juo et al., 1995). With the increasing soil depth, an increase in soil $\mathrm{pH}$ was noted compared to surface soil. This might be due to the downward movement of lime with percolating water to sub-surface soil (Hao \& Chang, 2003). Farmyard manure has been reported to increase the $\mathrm{pH}$ of the acid soils (Ashiono et al., 2005). The use of $\mathrm{N}$ fertilizers alone or in combination with FYM reduced the soil $\mathrm{pH}$ as compared to the control plots. This study further showed that the ability of $\mathrm{N}$ fertilizers to reduce soil

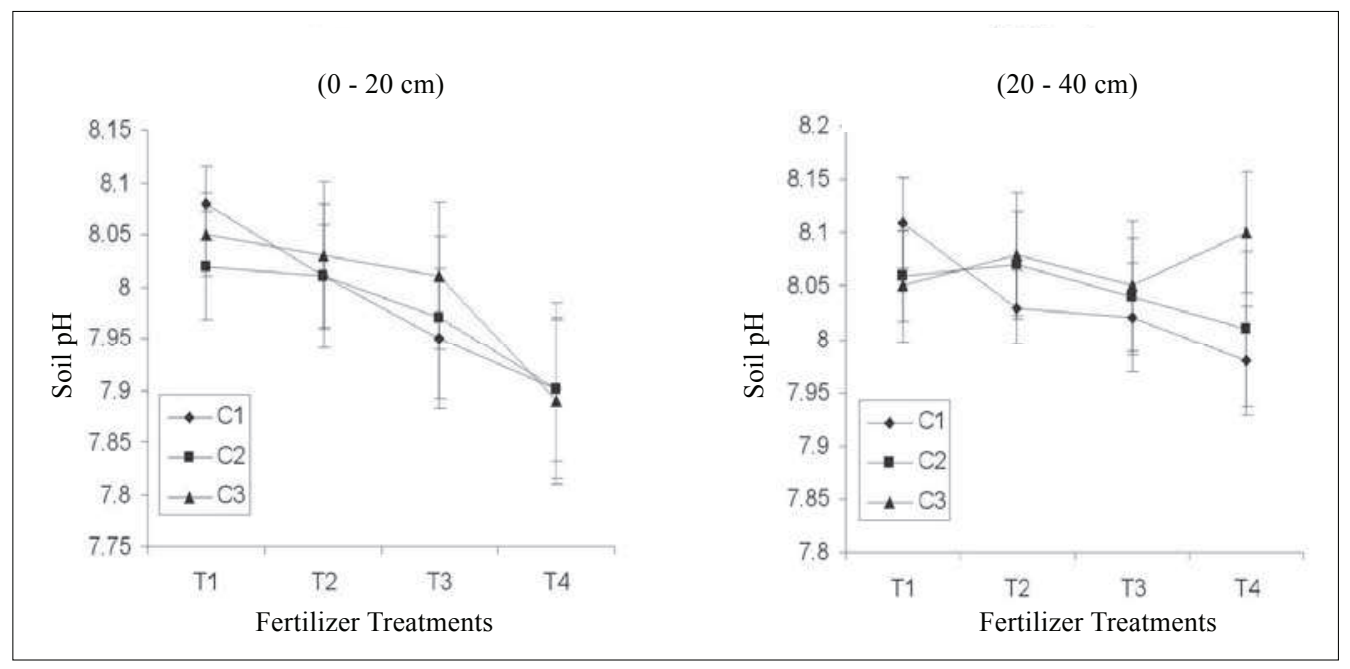

Figure 5: Interaction effect between fertilizer treatments and cropping patterns on soil $\mathrm{pH}$ in surface and sub-surface soil 
$\mathrm{pH}$ of alkaline soils is not affected by the combined use with farmyard manure. Regarding the cropping patterns effect, it was noted from the data (Table 8), that there was no significant reduction in soil $\mathrm{pH}$ both in the surface and sub-surface soil. The data analysis showed that the interaction effect between the fertilizer treatments and the cropping patterns on soil $\mathrm{pH}$ was not significant both in the surface and sub-surface soil. Thus, any change in soil $\mathrm{pH}$ was due to the individual effect of fertilizer treatments in surface soil.

\section{Electrical conductivity $\left(d S \boldsymbol{m}^{-1}\right)$}

The results revealed that the electrical conductivity $\left(\mathrm{EC}_{1: 5}\right)$ in both the surface and the sub-surface soil significantly $(\mathrm{p}<0.01)$ increased with fertilizer application. The maximum increase in surface soil was observed in the treatment receiving mixed organic and inorganic fertilizers (T4), which was $40 \%$ higher than in the control, $30 \%$ higher than in the farmer's practice (T2) and $6.7 \%$ higher than in the recommended NPK (T3). A similar trend was observed in sub-surface soil where T4 recorded 48, 36 and $12 \%$ higher EC over the control, farmer's practice (T2) and the recommended NPK dose (T3), respectively. These finding are in line with the findings of Stamatiadis et al. (1999) who found a 1.5 unit increase in the electrical conductivity (EC) with the surface application of ammonium nitrate. These results also confirmed the findings of Hao and Chang (2003) who reported that livestock manure contains a considerable amount of salt and the continued application to agricultural land may result in an accumulation of salt in soil. Based on the averaged data of treatments, a $3 \%$ increase in EC was observed in sub-surface soil over the surface soil showing the downward movement of soluble ions $\left(\mathrm{Na}^{+}, \mathrm{K}^{+}, \mathrm{Mg}^{2+}, \mathrm{Cl}^{-}, \mathrm{HCO}_{3}^{-}\right)$in the eroded soil. The cropping pattern effect on soil $\mathrm{EC}_{(1: 5)}$ was not significant both in the surface $(0-20 \mathrm{~cm})$ and sub-surface $(20-40$ $\mathrm{cm})$ soil. Data analysis showed that the interaction effect between fertilizer treatments and cropping patterns on soil $\mathrm{EC}_{1: 5}$ was highly significant $(\mathrm{p}<0.01)$ in surface soil and non-significant in sub-surface soil. Thus, the variation in soil $\mathrm{EC}_{(1: 5)}$ in surface soil was due to the combined effect of fertilizer application at various doses and in various forms and at various rates to different cropping patterns. $\mathrm{EC}_{(1: 5)}$ was the highest in $\mathrm{C} 1$ and lowest in $\mathrm{C} 2$ from $\mathrm{T} 1$ to $\mathrm{T} 3$ treatments. But the situation was reversed in the case of $\mathrm{T} 4 \times \mathrm{C} 2$ where the soil $\mathrm{EC}_{(1: 5)}$ was the maximum and this might be due to the salts accumulation from FYM mineralization and the salts saved from leaching to subsoil due to higher content of soil OM.

\section{AB-DTPA extractable micro-nutrients (Fe, $\mathrm{Zn}, \mathrm{Mn}, \mathrm{Cu})$}

The fertilizer treatments significantly $(\mathrm{p}<0.01)$ increased the micro-nutrient concentration in both the surface and sub-surface soil. It was observed (Table 7) that mixed application of farmyard manure and mineral fertilizer showed the highest increase in micro-nutrient concentration with 40.6,38 and $27.5 \%$ increase in Fe over the control (T1), farmers practice (T2) and recommended NPK (T3) in surface soil, respectively. Similarly, T4 recorded 72, 56.6 and $33 \%$ increase in $\mathrm{Zn}$ concentration, 56,42 and $40 \%$ increase in $\mathrm{Mn}$ concentration over the $\mathrm{T} 1, \mathrm{~T} 2$ and T3, respectively, and 66.7, 61 and $55.6 \%$ increase in $\mathrm{Cu}$ concentration in surface soil, respectively. A similar trend of increase in micro-nutrients with respect to treatments was observed in sub-surface soil. Laboratory analysis results of farmyard manure showed $121.1 \mathrm{mg}$ $\mathrm{kg}^{-1} \mathrm{Mn}, 45.1 \mathrm{mg} \mathrm{kg}^{-1} \mathrm{Zn}, 18.3 \mathrm{mg} \mathrm{kg}^{-1} \mathrm{Cu}$ and $1100 \mathrm{mg}$

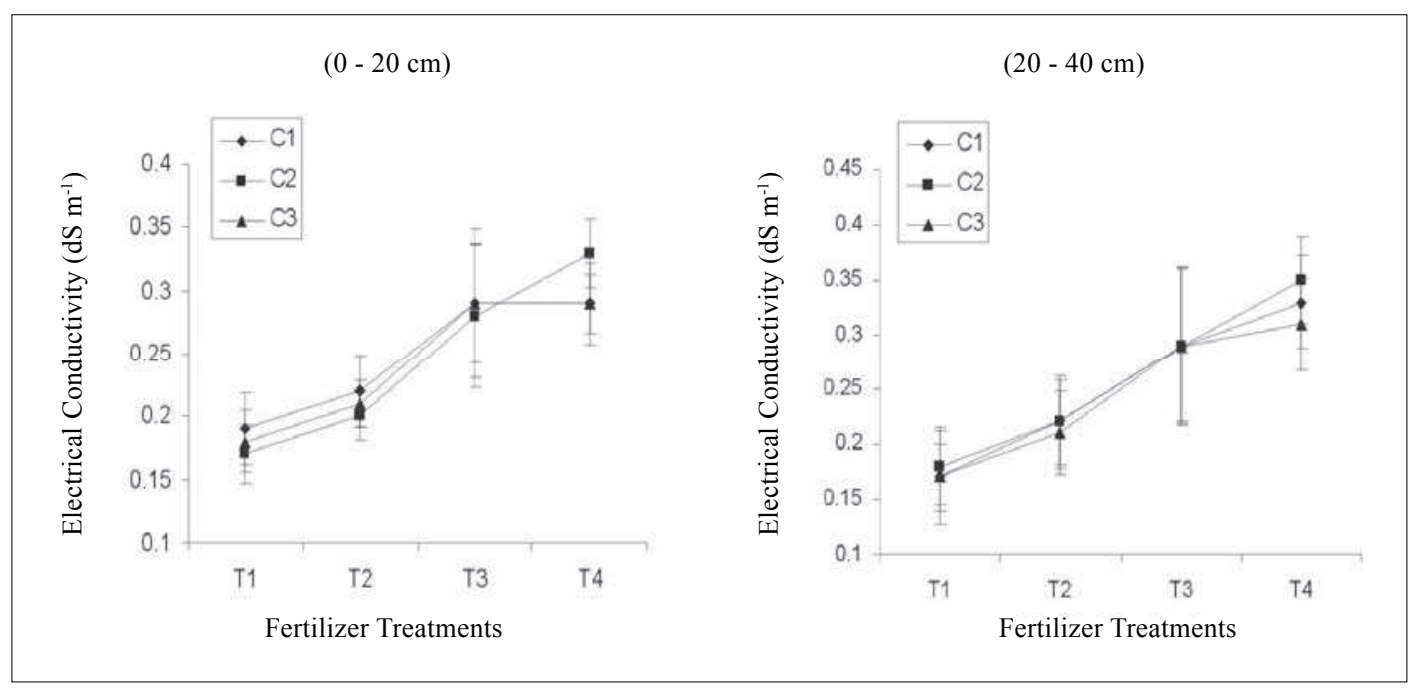

Figure 6: Interaction effect between fertilizer treatments and cropping patterns on soil $\mathrm{EC}_{1: 5}$ in surface and sub-surface soil 


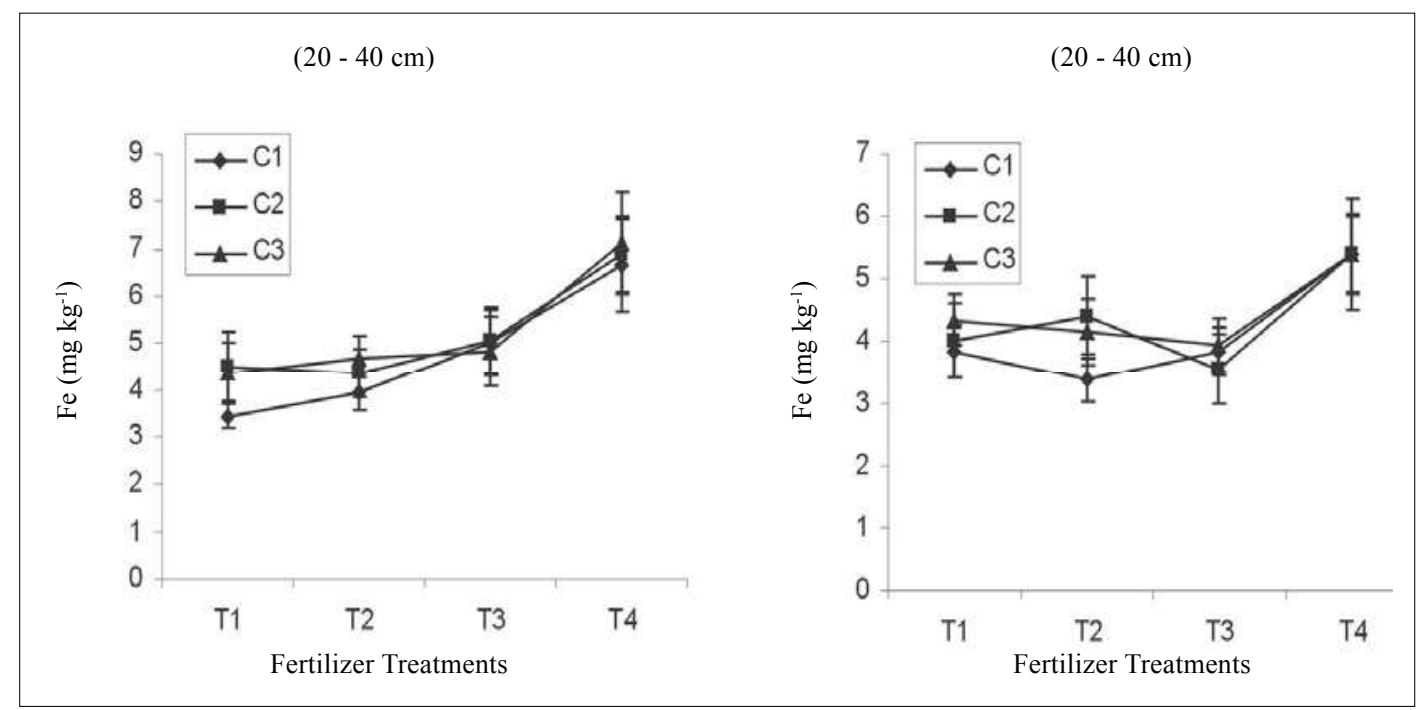

Figure 7: Interaction effect between fertilizer treatments and cropping patterns on micro-nutrients Fe in surface $(0-20 \mathrm{~cm})$ and sub-surface $(20-40 \mathrm{~cm})$ soil

$\mathrm{kg}^{-1} \mathrm{Fe}$. A gradual increase in the concentration of these nutrients was also observed with time due to continuous application of farmyard manure to soil. Many researchers have confirmed that farmyard manure application to agricultural soils increase soil nutrient concentration including micro-nutrients (Timsina \& Connor, 2001; Dawe et al., 2003; Pratt, 2008). Based on the average data over treatments, it was observed that micro-nutrient concentration also decreased with depth and a 14, 23, 18 and $7.7 \%$ decrease in $\mathrm{Fe}, \mathrm{Zn}, \mathrm{Mn}$ and $\mathrm{Cu}$ was observed in sub-surface soil over the surface soil, respectively. The changing concentrations of micronutrients in sub-surface soil might be due to the downward mobility of these nutrients or the organic matter particles with water into sub-surface soil. Toribio and Romanya (2006) reported a higher mobility of $\mathrm{Zn}$ and $\mathrm{Cu}$ as compared to the control plots.

It was further observed (Table 8) that cropping patterns effect on AB-DTPA extractable micro-nutrient concentration in soil was not significant both in the surface and sub-surface soil. The data analysis further showed that interaction effect between fertilizer treatments and cropping patterns was only significant on AB-DTPA extractable $\mathrm{Fe}(\mathrm{p}<0.01)$ and $\mathrm{Cu}(\mathrm{p}<0.05)$ in sub-surface soil while it was not significant with regard to the other micro-nutrients at the same depth and all four micro-nutrients in surface soil. Thus, any variation in $\mathrm{Fe}$ and $\mathrm{Cu}$ in sub-surface soil was due to the combined effect of fertilizers and cropping patterns, while the rest of the micro-nutrients in sub-surface soil and the four micro-nutrients under study in the surface soil changed in content due to the individual effect of either the fertilizer treatment or the cropping pattern.

\section{Variation in soil fertility status with time (temporal variation)}

Statistical analysis of the combined data over seasons revealed that mineral $\mathrm{N}$, AB-DTPA extractable $\mathrm{P}, \mathrm{K}$ and soil organic matter $(\mathrm{OM})$ content were significantly $(\mathrm{p}<0.01)$ increased by the combined organic and inorganic fertilizer application and the inclusion of legumes in cropping patterns at both depths. In the surface soil $(0-20 \mathrm{~cm})$, mineral $\mathrm{N}$, AB-DTPA extractable $\mathrm{P}$, and $\mathrm{K}$ content showed 42,50 and $30 \%$ increase, respectively, whilst soil OM content showed a 2.5 times increase during fall 2007 over spring 2006 (Table 9). A similar pattern was observed in sub-surface soil. It was noted from further statistical analysis that soil OM content showed a significant correlation with mineral N, AB-DTPA extractable P and $\mathrm{K}$ contents $(\mathrm{r}=0.95,0.87$ and 0.70 respectively) in surface soil and sub-surface soil $(r=0.84,0.98$ and 0.89 , respectively). These results showed that the mineral nutrient concentration gradually increased at both depths over the years. Nitrate accumulated in soil either from mineralization of organic matter or from the mineral fertilizer application (Crews \& Peoples, 2004). The residual effect of the applied $\mathrm{P}$ i.e application of $\mathrm{P}$ in excess of that removed by harvested crops, resulted in a build-up of soil P reserves with time (McCullum, 1991) and the decomposition of organic fertilizers liberated the P locked in it (Guo et al., 2008). Mineral $\mathrm{K}$ application and those coming from the decomposition of farmyard manure resulted in a significant increase of available $\mathrm{K}$ content in both surface and sub-surface soil over time (Kaihura et al., 1999). Farmyard manure showed a residual effect because of slow mineralization and its continuous application increased the organic 


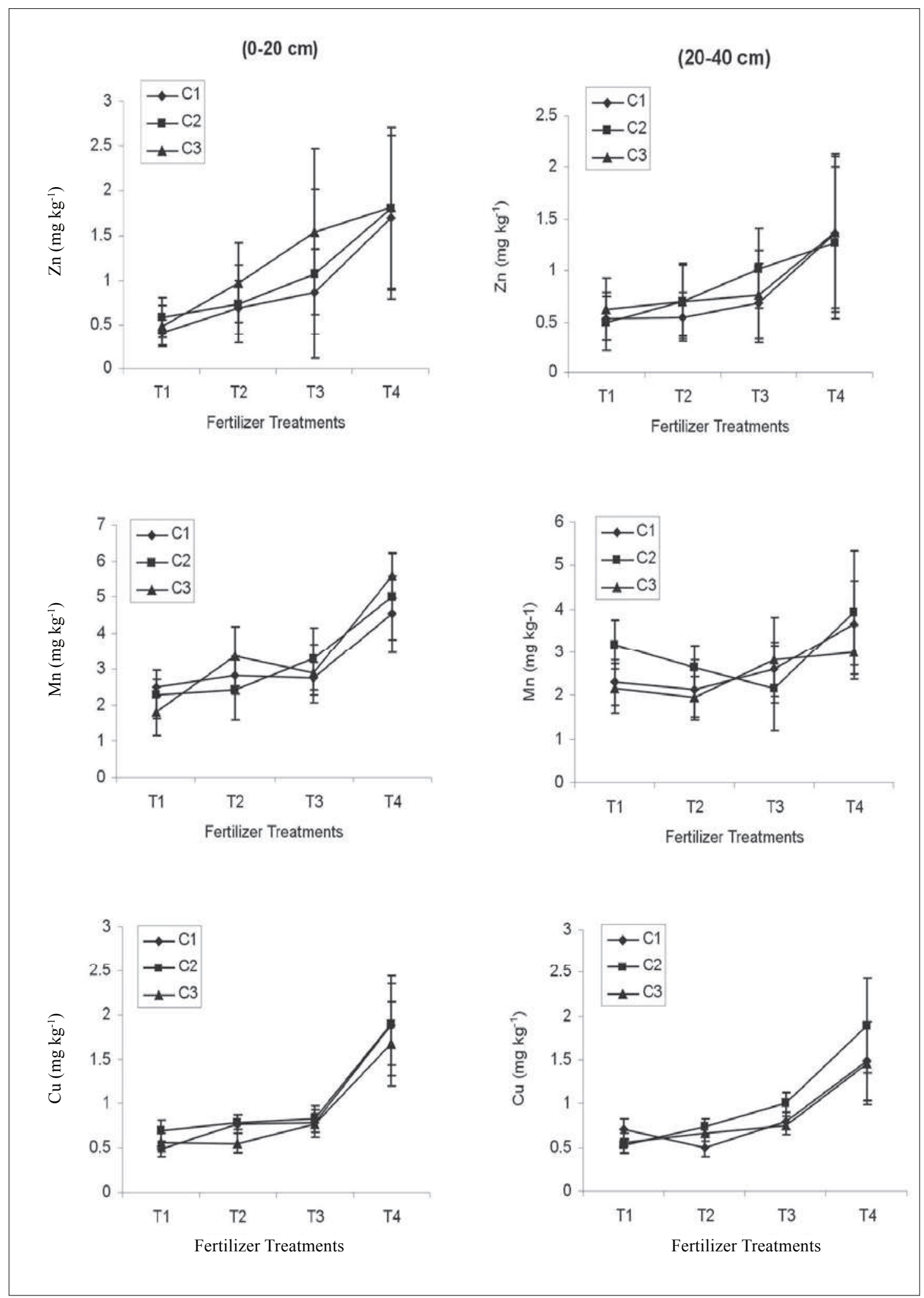

Figure 6: Interaction effect between fertilizer treatments and cropping patterns on micro-nutrients $\mathrm{Zn}, \mathrm{Mn}$ and $\mathrm{Cu}$ in surface $(0-20 \mathrm{~cm})$ and sub-surface $(20-40 \mathrm{~cm})$ soil 
Table 9: Combined effect of soil amendments and cropping patterns on soil fertility status with time

\begin{tabular}{|c|c|c|c|c|c|c|c|c|c|c|}
\hline Parameters & $\begin{array}{c}\text { Spring } \\
2006\end{array}$ & $\begin{array}{c}\text { Fall } \\
2006\end{array}$ & $\begin{array}{c}\text { Spring } \\
2007\end{array}$ & $\begin{array}{l}\text { Fall } \\
2007\end{array}$ & $\begin{array}{l}\text { LSD } \\
(<0.05)\end{array}$ & $\begin{array}{c}\text { Spring } \\
2006\end{array}$ & $\begin{array}{c}\text { Fall } \\
2006\end{array}$ & $\begin{array}{c}\text { Spring } \\
2007\end{array}$ & $\begin{array}{c}\text { Fall } \\
2007\end{array}$ & $\begin{array}{c}\text { LSD } \\
(<0.05)\end{array}$ \\
\hline & \multicolumn{5}{|c|}{----------------- 0 - $20 \mathrm{~cm}$--------------- } & \multicolumn{5}{|c|}{--- 20 - 40 cm ---- } \\
\hline $\operatorname{Min} . \mathrm{N}\left(\mathrm{mg} \mathrm{kg}^{-1}\right)$ & 18.3 & 21.4 & 24.7 & 25.9 & 2.8 & 14.7 & 15.3 & 20.6 & 21.3 & 4.8 \\
\hline $\mathrm{O} . \mathrm{M}\left(\mathrm{g} \mathrm{kg}^{-1}\right)$ & 2.8 & 6.0 & 7.3 & 7.3 & 0.7 & 2.8 & 5.0 & 5.9 & 6.0 & 0.3 \\
\hline Soil $\mathrm{pH}$ & 7.86 & 7.84 & 7.85 & 7.8 & 0.02 & 7.89 & 7.89 & 7.9 & 7.88 & ns \\
\hline E.C. $\left(\mathrm{dS} \mathrm{m}^{-1}\right)$ & 0.23 & 0.19 & 0.22 & 0.33 & 0.01 & 0.23 & 0.18 & 0.20 & 0.38 & 0.01 \\
\hline \multicolumn{11}{|c|}{ AB-DTPA extractable $\left(\mathrm{mg} \mathrm{kg}^{-1}\right)$} \\
\hline $\mathrm{P}$ & 5.0 & 5.6 & 6.7 & 7.5 & 0.9 & 0.9 & 3.3 & 4.6 & 5.4 & 0.4 \\
\hline K & 74.0 & 77.1 & 81.6 & 96.1 & 4.3 & 63.0 & 65.4 & 72.9 & 71.0 & 4.4 \\
\hline $\mathrm{Fe}$ & 3.80 & 4.33 & 5.60 & 6.57 & 0.57 & 3.40 & 3.49 & 4.62 & 5.70 & 0.41 \\
\hline $\mathrm{Zn}$ & 0.10 & 0.44 & 1.14 & 2.53 & 0.36 & 0.11 & 0.27 & 0.88 & 2.08 & 0.22 \\
\hline $\mathrm{Mn}$ & 1.57 & 2.83 & 3.75 & 4.90 & 0.42 & 1.02 & 2.24 & 2.64 & 4.02 & 0.47 \\
\hline $\mathrm{Cu}$ & 0.45 & 0.89 & 1.15 & 1.39 & 0.2 & 0.43 & 0.81 & 1.09 & 1.35 & 0.28 \\
\hline
\end{tabular}

Data have been combined from 3 cropping patterns, 4 fertilizer treatments and 3 replications

matter content of the soil (Patra et al., 2000). A long term experiment by Goyal et al. (2006) revealed that the amount of soil organic matter and mineralizable $\mathrm{C}$ and $\mathrm{N}$ increased with the addition of mineral fertilizers.

Crop season effect on soil $\mathrm{pH}$ and $\mathrm{EC}$ was significant $(\mathrm{p}<0.01)$ only in the surface soil $(0-20 \mathrm{~cm})$ only. It was observed that soil fertility management practices (fertilizer treatments and cropping patterns) showed a decreasing trend in soil $\mathrm{pH}$ in the surface soil $(0-20$ $\mathrm{cm}$ ) with time (from spring 2006 to fall 2007), whilst in the sub-surface soil $(20-40 \mathrm{~cm})$ the trend was inconsistent (Table 9). Aref and Wander (1998) reported lowering of soil $\mathrm{pH}$ with long term fertilizer applications. Farmyard manure has been reported to increase the $\mathrm{pH}$ of the acid soils (Ashiono et al., 2005) but due to the use of $\mathrm{N}$ fertilizers alone or in combination with FYM that reduced the soil $\mathrm{pH}$. It was also observed that soil $\mathrm{EC}_{1: 5}$ increased with time at both depths, which might be due to the mineral fertilizer application or due to the salts coming from farmyard manure. Livestock manure contains a considerable amount of salt and the continued application to agricultural land may result in an accumulation of salt in soil (Hao \& Chang, 2003).

Soil fertility management effect on soil micro nutrients $\mathrm{Fe}, \mathrm{Zn}, \mathrm{Mn}$, and $\mathrm{Cu}$ was highly significant ( $\mathrm{p}<$ $0.01)$ at both depths $(0-20 \mathrm{~cm}$ and $20-40 \mathrm{~cm})$. It was observed that the concentration of these micro-nutrients increased with time at different soil depths. At each soil depth, the lowest value was found in spring 2006 for each micro-nutrient while the highest value was recorded during the fall 2007. Many researchers have confirmed that farmyard manure application to agricultural soils increase the soil nutrient concentration including micronutrients (Pratt, 2008).

\section{CONCLUSION}

It is concluded that there has been sufficient potential to improve soil fertility of the severely eroded Missa gullied soil. This cannot be achieved solely with the practice of the recommended dose of mineral fertilizers. It is also necessary to obtain $50 \%$ of the inorganic $\mathrm{N}$ from organic sources like farmyard manure that also supplements the rest of the nutrients in eroded soil. Moreover, legumes must be included in the traditional cereal-cereal cropping pattern to further improve the $\mathrm{N}$ input, soil $\mathrm{OM}$ and reduce the velocity of water flow on these soils.

\section{Acknowledgement}

The authors are thankful to the Higher Education Commission of Pakistan for financial support.

\section{REFERENCES}

1. Ali S., Bhatti A.U., Khan F. \& Ghani A. (2008). Performance of mungbean in wheat-mungbean system under integrated plant nutrient management on eroded lands. Sarhad Journal of Agriculture 24(3): 445 - 452. 
2. Anderson R.L. (2005). Are some crops synergistic to following crops. Agronomy Journal 97: 7 - 10.

3. Aref S. \& Wander M.M. (1998). Long term trends of corn yield and soil organic matter in different crop sequences and soil fertility treatments on the Morrow plots. Advances in Agronomy 62: 153 - 161.

4. Ashiono G.B., Wasike W., Ouma J.P., Gatwiku S.W. \& Gachuki P.N. (2005). Residual effects of farmyard manure on stover and grain yield of cold tolerant dual purpose sorghum in the dry highlands of Kenya. Journal of Agronomy 4(4): 300 - 303.

DOI: http://dx.doi.org/10.3923/ja.2005.300.303

5. Ayaga G., Todd A. \& Brookes P.C. (2006). Enhanced biological cycling of phosphorus increases its availability to crops in low-input sub-Saharan farming systems. Soil Biology and Biochemistry 38(1): $81-90$.

DOI: http://dx.doi.org/10.1016/j.soilbio.2005.04.019

6. Banning N.C., Grant C.D., Jones D.L. \& Murphy D.V. (2008). Recovery of soil organic matter, organic matter turnover and nitrogen cycling in a post-mining forest rehabilitation chronosequence. Soil Biology and Biochemistry 40(8): $2021-2031$.

DOI: http://dx.doi.org/10.1016/j.soilbio.2008.04.010

7. Basu M., Bhadoria P.B.S. \& Mahapatra S.C. (2008). Growth, nitrogen fixation, yield and kernel quality of peanut in response to lime, organic and inorganic fertilizer levels. Bioresource Technology 99(11): 4675 - 4683.

DOI: http://dx.doi.org/10.1016/j.biortech.2007.09.078

8. Bengtsson H., Oborn I., Jonsson S., Nilsson I. \& Andersson A. (2003). Field balances of some mineral nutrients and trace elements in organic and conventional dairy farminga case study at Öjebyn, Sweden. European Journal of Agronomy 20(1-2): $101-116$.

9. Blaise D., Singh J.V., Bonde A.N., Tekale K.U. \& Mayee C.D. (2005). Effects of farmyard manure and fertilizers on yield, fibre quality and nutrient balance of rain-fed cotton (Gossypium hirsutum). Bioresource Technology 96(3): $345-349$.

DOI: http://dx.doi.org/10.1016/j.biortech.2004.03.008

10. Bremner J.M. (1996). Chemical methods-nitrogen-total. Methods of Soil Analysis (ed. D.L. Sparks), pp. 1085 1122. Soil Science Society of America Book Series No.5, Madison, Wisconsin, USA.

11. Bullock D.G. (1992). Crop rotation: critical review. Plant Science 11: $309-326$.

12. Campbell C.A., Beiderbecke V.O., Center R.P. \& Lafond G.P. (1991). Effect of crop rotations and cultural practices on soil organic matter, microbial biomass and respiration in a thin black chernozem. Canadian Journal of Soil Science 71: $363-376$.

DOI: http://dx.doi.org/10.4141/cjss91-035

13. Christensen B.T. (1988). Effects of animal manure and mineral fertilizer on the total carbon and nitrogen contents of soil size fractions. Biology and Fertility of Soils 5: $304-307$.

DOI: http://dx.doi.org/10.1007/BF00262136
14. Courtney R.G. \& Mullen G.J. (2008). Soil quality and barley growth as influenced by the land application of two compost types. Bioresource Technology 99(8): 2913 2918.

DOI: http://dx.doi.org/10.1016/j.biortech.2007.06.034

15. Crews T.E. \& Peoples M.B. (2004). Legume versus fertilizer sources of nitrogen: ecological tradeoffs and human needs. Agriculture, Ecosystems and Environment 102: 279 - 297. DOI: http://dx.doi.org/10.1016/j.agee.2003.09.018

16. Dalal R.C. \& Mayer R.J. (1986). Long-term trends in fertility of soils under continuous cultivation and cereal cropping in southern Queensland. 11. Total organic carbon and its rate of loss from the soil profile. Australian Journal of Soil Research 24: $281-292$.

DOI: http://dx.doi.org/10.1071/SR9860281

17. Dawe D., Dobermann A., Ladha J.K., Yadav R.L., Bao L., Gupta R.K., Lal P., Sanaullah G., Sariam O., Singh Y., Swarup A. \& Zhen Q.X. (2003). Do organic amendments improve yield trends and profitability in intensive rice systems? Field Crops Research 83: $191-213$.

18. Dressel J., Weigelt W. \& Mockel D. (1993). Changes in the nutrient potential of soil according to long-term dressing of farmyard manure and mineral fertilizer. Agribiological Research 4(46): 321 - 330.

19. Evans J., Fettell N.A., Coventry D.R., O'Connor G.E., Walsgott D.N., Mahoney J. \& Armstrong E.L. (1991). Wheat response after temperate crop legumes in SouthEastern Australia. Australian Journal of Agriculture Research 42: 31 - 43.

DOI: http://dx.doi.org/10.1071/AR9910031

20. Fox R.H. \& Hoftinan L.D. (1981). The effect of $\mathrm{N}$ fertilizer source on grain yield, $\mathrm{N}$ uptake, soil $\mathrm{pH}$, and lime requirement in no-till corn. Agronomy Journal 73: $891-895$.

21. Fujita K., Ofosu-Budu K.G. \& Ogata S. (1992). Biological nitrogen fixation in mixed legume-cereal cropping systems. Plant \& Soil 141: 155 - 175.

DOI:http://dx.doi.org/10.1007/BF00011315

22. Gomez K.A. \& Gomez A.A. (1984). Statistical Procedures for Agricultural Research, $2^{\text {nd }}$ edition, pp. 680. John Willey \& Sons, New York, USA.

23. Goyal S., Sakamoto K., Inubushi L. \& Kamaewada K. (2006). Long-term effects of inorganic fertilization and organic amendments on soil organic matter and soil microbial properties in Andisols. Archives of Agronomy and Soil Science 52(6): 617 - 625.

DOI: http://dx.doi.org/10.1080/03650340601048595

24. Guo S.L., Dang T.H. \& Hao M.D. (2008). Phosphorus changes and sorption characteristics in a calcareous soil under long-term fertilization. Pedosphere 18(2): 248 256.

25. Hao X. \& Chang C. (2003). Does long-term heavy cattle manure application increase salinity of a clay loam soil in semi-arid southern Alberta? Agriculture, Ecosystems and Environment 94(1): $89-103$.

26. Jokela W.E. (1992). Nitrogen fertilizer and dairy manure 
effects on corn yield and soil nitrate. Soil Science Society of America Journal 56: 148 - 154.

27. Juo A.S.R., Dabiri A. \& Franzluebbers K. (1995). Acidification of a kaolinitic Alfisol under continuous cropping with nitrogen fertilization. Plant and Soil 171: $245-253$.

DOI:http://dx.doi.org/10.1007/BF00010278

28. Kaihura F.B.S., Kullaya I.K., Kilasara M., Aune J.B., Singh B.R. \& Lal R. (1999). Soil quality effects of accelerated erosion and management systems in three eco-regions of Tanzania. Soil and Tillage Research 53(1): 59 - 70.

29. Kue S. (1996). Chemical methods-phosphorus. Methods of Soil Analysis (ed. D.L. Sparks), pp. 869 - 919. Soil Science Society of America Book Series No.5, Madison, Wisconsin, USA.

30. McLean E. O. (1982). Soil pH and lime requirement. Methods of Soil Analysis (eds. A.L. Page, R.H Miller \& D.R. Keeney) Part 2, $2^{\text {nd }}$ edition, pp. $209-223$. American Society of Agronomy, Madison, Wisconsin, USA.

31. McCullum R.E. (1991). Build up and decline in soil P: 30 years trend. Agronomy Journal 83: $77-85$.

32. Monaco S., Hatch D.J., Sacco D., Bertora C. \& Grignani C. (2008). Changes in chemical and biochemical soil properties induced by 11-yr repeated additions of different organic materials in maize-based forage systems. Soil Biology and Biochemistry 40(3): $608-615$.

33. Morari F., Lugato E. \& Giardini L. (2008). Olsen phosphorus, exchangeable cations and salinity in two longterm experiments of north-eastern Italy and assessment of soil quality evolution. Agriculture, Ecosystems and Environment 124(1-2): 85 - 96.

DOI:http://dx.doi.org/10.1016/j.agee.2007.08.001

34. Mulvaney R.L. (1996). Chemical methods - nitrogen inorganic forms. Methods of Soil Analysis, part 3 (ed. D.L. Sparks), pp. 595 - 624. Soil Science Society of America Book Series No.5, Madison, Wisconsin, USA.

35. Mussgnug F., Becker M., Son T.T., Buresh R.J. \& Vlek P.L.G. (2006). Yield gaps and nutrient balances in intensive, rice-based cropping systems on degraded soils in the Red River Delta of Vietnam. Field Crops Research 98(2-3): $127-140$.

DOI: http://dx.doi.org/10.1016/j.fcr.2005.12.012

36. Nelson D.W. \& Sommers L.E. (1982). Total carbon, organic carbon, and organic matter. Methods of Soil Analysis (ed. A.L. Page), $2^{\text {nd }}$ edition, pp. $574-577$. American Society of Agronomy, Madison, Wisconsin, USA.

37. Patra D.D., Anwar M. \& Chaud S. (2000). Integrated nutrient management and waste recycling for restoring soil fertility and productivity in Japanese mint and mustard sequence in Uttar Pradesh, India. Agriculture, Ecosystems and Environment 80: $267-275$.

38. Pratt R.G. (2008). Fungal population levels in soils of commercial swine waste disposal sites and relationships to soil nutrient concentrations. Applied Soil Ecology 38(3): $223-229$.

DOI:http://dx.doi.org/10.1016/j.apsoil.2007.10.013
39. Purakayastha T.J., Rudrappa L., Singh D., Swarup A. \& Bhadraray S. (2008). Long-term impact of fertilizers on soil organic carbon pools and sequestration rates in maize-wheat-cowpea cropping system. Geoderma 144(12): $370-378$.

DOI: http://dx.doi.org/10.1016/j.geoderma.2007.12.006

40. Rhoades J.D. (1996). Chemical methods: salinity; electrical conductivity and total dissolved salts. Methods of Soil Analysis (ed. D.L. Sparks), pp. 417 - 436. American Society of Agronomy, Madison, Wisconsin, USA.

41. Simek M., Hopkins D.W., Kalcik J., Picek T., Santruckove H., Stana J. \& Travnik K. (1999). Biological and chemical properties of arable soils affected by long term organic and inorganic fertilizer applications. Biology and Fertility of Soils 29: $300-308$.

DOI: http://dx.doi.org/10.1007/s003740050556

42. Soltanpour P.N. \& Schwab A.P. (1977). A new soil test for simultaneous extraction of macro and micro nutrients in alkaline soils. Communication in Soil Science and Plant Analysis 8: 195 - 207.

DOI: http://dx.doi.org/10.1080/00103627709366714

43. Stamatiadis S., Werner M. \& Buchanan M. (1999). Field assessment of soil quality as affected by compost and fertilizer application in a broccoli field (San Benito County, California). Applied Soil Ecology 12(3): 217 - 225.

44. Steel R.G.D. \& Torri J.H. (1980). Principles and Procedures of Statistics; A Biometrical Approach, $2^{\text {nd }}$ edition, pp. 633. McGraw-Hill, New York, USA.

45. Swarup A. (2001). Lessons from Long-term Fertility Experiments. Project Coordinating Cell, Indian Council for Agriculture Research, Indian Institute of Soil Science, Bhopal, India.

46. Tagar S. \& Bhatti A.U. (1996). Soil physical properties. Soil Science (eds. B. Elena \& R. Bantel), pp. 250. National Book Foundation, Islamabad, Pakistan.

47. Timsina J. \& Connor D.J. (2001). Productivity and management of rice-wheat cropping systems: issues and challenges. Field Crops Research 69: 93 - 132.

48. Toribio M. \& Romanya J. (2006). Leaching of heavy metals $(\mathrm{Cu}, \mathrm{Ni}$ and $\mathrm{Zn})$ and organic matter after sewage sludge application to Mediterranean forest soils. Science of the Total Environment 363(1-3): $11-21$.

DOI: http://dx.doi.org/10.1016/j.scitotenv.2005.10.004

49. United States Department of Agriculture (1998). Key to Soil Taxonomy, $8^{\text {th }}$ edition. Natural Resource Conservation Service, Whitten Building, $14^{\text {th }}$ and Independence Avenue, SW, Washington, DC, USA.

50. US Salinity Laboratory Staff (1954). Alkaline earth carbonates from acid nutralization (Method 23c). Diagnosis and Improvement in Saline and Alkali Soils (ed. L.A. Richard), pp. 105. Soil and Water Conservation Research Branch, Agricultural Research Service, USA.

51. Ussiri D.A., Lal R. \& Jacinthe P.A. (2006). Postreclamation land use effects on properties and carbon sequestration in mine soils of southeastern Ohio. Soil Science 171: $261-271$. 
DOI:http://dx.doi.org/10.1097/01.ss.0000199702.68654.1e

52. Wartiainen I., Eriksson T., Zheng W. \& Rasmussen U. (2008). Variation in the active diazotrophic community in rice paddy-NIFH PCR-DGGE analysis of rhizosphere and bulk soil. Applied Soil Ecology 39: 65 - 75.

DOI: http://dx.doi.org/10.1016/j.apsoil.2007.11.008

53. Wilson G.F., Lal R. \& Okigbo B.N. (1982). Effects of cover crops on soil structure and on yield of subsequent arable crops grown under strip tillage on an eroded Alfisol. Soil and Tillage Research 2: $233-250$.

54. Yang Z., Singh B.R. \& Hansen S. (2007). Aggregate associated carbon, nitrogen and sulfur and their ratios in long-term fertilized soils. Soil and Tillage Research 95(1-2): $161-171$.

55. Yoo S.H., Jung Y.S. \& Shin Y.H. (1974). Deterioration of the physical and chemical properties of vinyl house soils by continuous vegetable cropping. Journal of the Korean Society of Soil Fertility 7: $227-234$.

56. Zhao M., Zhou J. \& KalbitzK. (2008). Carbon mineralization and properties of water-extractable organic carbon in soils of the south Loess Plateau in China. European Journal of Soil Biology 44(2): $158-165$. 